\title{
RECENT DEVELOPMENTS IN THE LAW OF INTEREST TO OIL AND GAS LAWYERS
}

\author{
ROBERT P. DESBARATS, DONALD E. GREENFIELD AND LORNE W. CARSON*
}

\begin{abstract}
The purpase of this paper is to discuss recent developments in the law which are of interest to lawyers whase practices relate to the oil and gas industry. The poper deals with both judicial decisions and statutory developments during the last year. Some of the cases discussed do not pertain directly to the oil and gas industry, but have been included either because they involve situations analogous to those which occur in the oil and gas business or because they concern principles of law which are applicable to that industry. In order to place some limit on the scope of the paper, only federal and Alberta legislative developments are reported. In addition, we have not discussed federal income tax legislation. The review of legislation is effective as of April 1, 1986.
\end{abstract}

\section{MINES AND MINERALS}

\section{A. THE QUEEN IN RIGHT OF BRITISH COLUMBLA v. TENER '}

The plaintiff respondents were the registered owners of mineral claims granted by the British Columbia Crown in 1934. In 1939, Wells Gray Provincial Park was established, covering the lands subject to the mineral claims. In 1965, a statutory provision was enacted, requiring that a permit be obtained before a natural resource in a park could be exploited.

The owners of the claims were permitted to conduct certain work on the claims in 1973, but park use permits requested annually in 1974 through 1977 were not issued. In 1978, the Director of the Parks Branch advised the respondents that no new exploration or development work within a provincial park would be authorized.

The respondents contended that their interests had been expropriated and sought compensation equal to the initial acquisition costs and the expenditures made on the claims, totalling approximately $\$ 4,500,000$.

The Court considered whether the plaintiffs were entitled to compensation or damages under applicable statutes for money expended and lost opportunity and profits. An issue argued in the Courts below, whether the plaintiffs were entitled to damages at common law, was not argued in the Supreme Court of Canada.

The Court considered that the central issue was whether a refusal by the Crown to grant a park use permit gave rise to a statutory right to compensation. Two judgments were rendered by the Supreme Court of Canada.

In the majority judgment, it was held that the grantees of the mineral claims received a grant of all minerals in the lands together with the right to remove them. The proviso in the grant that it was subject to the laws for the time being in force respecting mineral claims did not authorize expropriation without compensation for purposes unrelated to mining regulation. The denial of access to the claim lands did not occur under the mining regulations; it constituted a recovery by the Crown of a part of the rights granted in 1937 and a taking for which compensation must be paid.

- Solicitors, Bennett Jones, Calgary, Alberta.

1. [1985] I S.C.R. 533, 36 R.P.R. 291. 
The Court held that the value of the loss to the respondents was to be determined by calculating the total value of the minerals and subtracting therefrom the value of the possibility of the future issuance of exploration and production permits.

\section{B. MARTIN MINE LTD. v. THE QUEEN IN RIGHT OF BRITISH COLUMBLA ${ }^{2}$}

Martin Mine Ltd. appealed a decision that a special placer mining lease had been forfeited.

The Court held that section 21 of the Law and Equity Act, ${ }^{3}$ which provides that a court may relieve against penalties and forfeitures, does not apply to statutory forfeitures.

\section{ATTORNEY GENERAL OF CANADA v. ATTORNEY GENERAL OF ALBERTA}

In 1973, the federal Government transferred management and control of the Bow River irrigation project to Alberta; included within the assets transferred were "all property, real and personal, ... . within the said Bow River Project area" and "[a]ll the lands and interests in land held by Canada including ... mineral rights (heretofore) under ... Project management".

The mines and minerals to which the dispute related were covered by certificates of title separate from titles covering surface rights. There were some mineral rights included in the Project which were covered by certificates of title which also covered surface rights. The disputed mineral titles were administered by the Department of Energy, Mines and Resources while the Project was administered by the Department of Regional Economic Expansion.

The Court held that the expression "mineral rights" was not qualified in the transfer agreement, so that there was no reason to regard it as including only mineral rights in land if the surface of the lands was in the Project and the surface and mines and minerals were contained in one title. The Court also held that there was nothing in the agreement to restrict the reference to "Canada's Bow River Project management" to assets administered by the Federal Department of Regional Economic Expansion, thereby excluding mineral titles administered by the Department of Energy, Mines and Resources. This conclusion was held to be reinforced by the use of the word "heretofore" which, in this context, meant "at any time since the acquisition".

2. (1985) 62 B.C.L.R. 107 (B.C.C.A.).

3. R.S.B.C. 1979, c. 224.

4. (1985) 63 N.R. 294 (F.C.A.). 


\section{INTERPRETATION OF CONTRACTS}

\section{A. ROYAL BANK OF CANADA v. JOFFRE RESOURCES LTD. AND JOFFRE OILS LTD.}

A farmout agreement provided that a farmee would earn an undivided interest in certain oil and gas rights from the farmor by conducting certain drilling operations. The farmor had exercised its right to participate in these drilling operations. The agreement provided that the farmee would be the operator of the drilling operations in accordance with the terms of an attached operating procedure. In accordance with the operating procedure, the farmee had obtained from the farmor an advance of funds on account of the farmor's share of estimated costs of operations. The drilling operations were completed. Actual costs were less than estimated with the result that the farmee was obligated to refund in excess of $\$ 100,000$ to the farmor. The farmee became insolvent and did not make the refund. Thereafter the farmee demanded a conveyance of the interests which it was entitled to earn.

The agreement provided that upon the farmee having carried out the drilling obligations and if it was not in default under the Agreement, it earned the specified interest. The Court interpreted this to mean that the farmee did not earn until it had satisfied two conjunctively expressed requirements. The farmor could not be ordered to transfer the interests because the farmee was in default under a term of the contract even though that term did not relate to the primary obligation of drilling, testing and completing the wells. The Court stated that a party who is in breach of an essential term of an agreement cannot obtain specific performance thereof. That principle does not normally extend to trivial breaches, but the failure to pay a sum in excess of $\$ 100,000$ could not be considered trivial.

The Court also held that since there was no explanation for the failure to make the refund, the only possible conclusion was that the failure was improper so that it was appropriate to award interest under section 15 of the Judicature Act. ${ }^{6}$ Interest was awarded at the rate of $10 \%$ from the date on which the last of the wells was completed until the date on which the Judgment Interest Act' came into force, after which interest was to run at $11 \%$.

\section{B. GREENBERG v. MEFFERT ${ }^{8}$}

This decision of the Ontario Court of Appeal is authority for the proposition that a person in whom discretion is vested by contract must exercise that discretion reasonably, honestly and in good faith.

The Court held that, on the facts of the case, the provisions in question were to be construed as imposing an objective standard of reasonableness. The matter to be decided was one that was easily susceptible of objective

S. [1985] 5 W.W.R. 75 (Alta. Q.B.).

6. R.S.A. 1980, c. J-1.

7. R.S.A. 1980, c. J-0.5.

8. (1985) 18 D.L.R. (4th) 548 (Ont. C.A.). 
measurement. The clause appeared in an employment manual prepared by the employer and weighted in its favour, with the result that any ambiguity or uncertainty ought to be interpreted against the employer. If one were to construe the discretionary power as being susceptible of subjective exercise, the contractual provision would be virtually meaningless.

\section{SASKATCHEWAN POWER CORPORATION and MANY ISLANDS PIPELINES LIMITED v. TRANSCANADA PIPELINES LIMITED'}

This was an action to recover alleged overpayments made under a 1969 gas purchase contract. The contract related to natural gas produced from wells in Alberta, and provided for an average price of $\$ 0.235$ per mcf. The contract granted Sask Power an option to purchase specified quantities of gas each year, upon giving at least 18 months prior written notice to TransCanada. After passage of the Petroleum Administration Act, ${ }^{10}$ the seller, TransCanada, charged the regulated price established pursuant to that Act which was greatly in excess of the contract price. Sask Power sued to recover the difference between the contract price and the regulated price. Sask Power advanced three contentions:

(a) the provisions of the Act "were ultra vires the Parliament of Canada, insofar as they prescribed prices to be paid for Alberta natural gas sold outside that province;

(b) the pricing regulations did not apply to the November, 1969 contract, as it predated the regulations; and

(c) the regulations did not apply to gas in respect of which Sask Power had exercised its option to purchase prior to the regulations being enacted.

The Court held that the price regulation provisions are part of a scheme to manage natural gas resources for the purpose of achieving policy goals, and that they are directed at the regulation of interprovincial and export trade in furtherance of that scheme. The Court held further that the fact that the provisions incidentally interfere with matters of property and civil rights within a province does not place them outside Parliament's jurisdiction.

The regulated prices were set by the Governor in Council upon the recommendation of the National Energy Board acting pursuant to the provisions of Part 4 of the National Energy Board Act. ${ }^{12}$ In 1981, the Supreme Court of Canada had ruled that the N.E.B. was not empowered to deal with the price to be paid for gas except incidentally in fixing transportation tolls. Sask Power argued that the regulated prices were without effect, because the Board was without jurisdiction to set prices.

The Saskatchewan Court of Queen's Bench held that the authority of the Governor in Council was not dependent upon jurisdiction of the N.E.B.

9. [1985] 5 W.W.R. 391, 42 Sask. R. 127 (Sask. Q.B.).

10. S.C. 1974-75-76, c. 47 [title am. 1980-81-82-83, c. 114, s. 1; now the Energy Administration Act].

11. Id.

12. R.S.C. 1970, c. $\mathrm{N}-6$. 
The Governor in Council could act upon any recommendation of the N.E.B., no matter how formulated.

Sask Power's third argument was that the Natural Gas Price Regulations, ${ }^{13}$ under which the regulated prices were set, did not apply to the 17 bcf of gas delivered during the 1976/77 contract year, notwithstanding that they came into effect in October, 1975, because Sask Power had exercised its option to purchase that gas in March, 1975. Subsection 51(1) of the Act ${ }^{14}$ authorized the establishment of prices at which various kinds of gas "are to be sold on or for delivery". Applying the primary rule of interpretation that words must be interpreted in the ordinary grammatical sense, the Court held that these words ought to be read as an authorization to prescribe prices at which various kinds of gas "are to be disposed of by sale or for delivery". Thus, the section applied to gas not already disposed of by sale when the legislation came into force, whether or not it was then subject to an existing agreement. The Court found it difficult to conceive that gas could be said to have been disposed of by sale until it had been delivered, and therefore held that the $17 \mathrm{bcf}$ was a purchase to which the Regulations applied.

The Court also cited a policy reason for this conclusion. Subsection 49(a) of the Act ${ }^{13}$ states that one of the purposes of Part 3 of the Act is to achieve a uniform price for gas used in Canada outside the province of production. By contract year $1979 / 80$, only $5.1 \%$ of TransCanada's Canadian sales were made under contracts entered into on or after November 1, 1975. Many of the contracts made before that date extended well into the 1990's and if subsection 51(1) was to be read in the manner contended by Sask Power, a uniform price could not be achieved for many years. The Court doubted that Parliament intended that result.

\section{MITSUI \& CO. v. OCELOT INDUSTRIES LTD. ${ }^{16}$}

This decision is one of several in litigation between Mitsui and Ocelot relating to the price to be paid for methanol supplied by Ocelot pursuant to a January 17,1980 supply agreement which provided that the price to be paid thereunder was to be the average of the published prices of Dupont and Celanese. In earlier litigation, it had been decided that this price mechanism no longer applied, since Dupont and Celanese had abandoned their practice of publishing price lists in June and July, 1982, respectively, with the result that the last published price lists no longer reflected current prices. In the previous litigation, it had been held that the price payable for methanol sold pursuant to the contract between June 30, 1982 and June 30, 1983 should be decided by arbitration in accordance with the supply agreement.

During the arbitration, Mitsui and Ocelot invited the arbitration board to fix a price for methanol sold between July 1, 1983 and December 31, 1984, as well. Mitsui invited the board to conclude that it had jurisdiction

13. C.R.C. 1978 , c. 1259.

14. Supra n. 10.

15. Id.

16. (1985) 62 A.R. 292 (Alta. Q.B.). 
to do so, whereas Ocelot took the position that the matter of jurisdiction was to be decided by a court. Mitsui, apparently concluding that the price set was too high, declined to pay the price set by the arbitration board for the period July 1, 1983 to December 31, 1984.

In the instant proceedings, the Court concluded that it was the clear intention of the parties, as reflected in the pricing provisions of the supply agreement, that the price lists upon which they were to rely were to be genuine in reflecting the actual price at which Dupont and Celanese sold methanol. The outdated published prices, while meaningless as an indicator of actual transactions then occurring, could not have been intended by the parties to form the basis for their pricing. Since the pricing mechanism had become inoperative, price was a matter for arbitration.

The Court further held that the price set by the arbitration board for the period July 1, 1983 to December 31, 1984 was binding on Mitsui and Ocelot, notwithstanding that the board felt it did not have jurisdiction to set the price for that period. Mitsui and Ocelot should be bound to their agreement that a price could be set by the board, subject to a court decision on jurisdiction. Neither party should be allowed to renege on this agreement. Although the Court did not expressly say so, the basis for this decision appears to be that Mitsui was precluded from taking a different position than that taken before the arbitration board by virtue of the doctrines of election and estoppel, being the argument advanced by Ocelot on this issue.

\section{E. ACCORD HOLDINGS LTD. v. EXCELSIOR LIFE INSURANCE "1"}

This case provides an example of the circumstances in which a borrower will be awarded damages for the breach of a loan commitment by a lender.

It was found that the commitment letter bound the lender to advance funds subject to the performance of certain conditions, one being the execution of formal security documents. However, the mortgage tendered by the lender for signature by the borrower contained a provision leaving the advancement of funds to the unfettered discretion of the lender. It was found that the lender had insisted that this term be contained in the mortgage and it was held that this insistence was a repudiation of the commitment letter, to which the borrower acquiesced, but in respect of which he was entitled to damages.

\section{F. DODGE v. EISENMAN ${ }^{\text {ts }}$}

The plaintiffs had entered into an agreement with the defendant in settlement of litigation, which provided that the plaintiffs would pay U.S. $\$ 2,250,000$ to the defendant on or before May 1, 1985 or transfer certain mining claims to the defendant. Transfers were executed and held by an escrow agent to be delivered if the payment was not made. At the time of entering into the agreement, and on May 1, 1985, the defendant did not have a licence under the Canadian Mining Regulations. ${ }^{19}$ Paragraph 8(4)(c)

17. (1985) 62 A.R. 234 (Alta. C.A.).

18. (1985) 23 D.L.R. (4th) 711 (B.C.C.A.).

19. C.R.C. 1978 , c. 1516 . 
[VOL. XXV, NO. 1

of the Regulations provides that "no person other than a licencee shall acquire any recorded claim or any interest therein by transfer". The plaintiffs did not pay the money and commenced this action to have the settlement agreement declared void on the grounds that it offended the Regulations.

The majority judgment adopted the following principle from Saint John's Shipping Corp. v. Joseph Rank Ltd.:20

\footnotetext{
A court should not hold that any contract ... is prohibited by statute uniess there is a ...

"necessary inference" ... that the statute so intended. If a contract has as its whole object the doing of the very act which the statute prohibits, ... that is a clear implication. But unless you get a clear implication, ... a court ought to be very slow to hold that a statute intends to interfere with the rights and remedies given by the ordinary law of contract.
}

The majority held that the object of the settlement agreement was not the violation of the Regulations. There was nothing in the contract, or in the surrounding circumstances, upon which to conclude that the arrangement of fended public policy.

The minority judgment was also in favour of the defendant, holding that the settlement agreement did not give the plaintiff a contingent interest in the claims at the time of execution but only the right to acquire them. The defendants had performed their obligations under the agreement by delivering the transfers to the escrow agent and were entitled to its benefits.

\section{G. HARVELA INVESTMENTS LTD. v. ROYAL TRUST FUND CO. OF CANADA (C.I.) LTD. ${ }^{21}$}

Royal Trust invited offers from two bidders for the purchase of shares in a company. The invitation included an undertaking by Royal Trust to accept the highest offer and a provision wherein it was stated that the offers must be confidential and must remain confidential until the time specified for submission of offers had elapsed. The House of Lords characterized this as a fixed bidding sale, rather than an auction sale.

One party's bid was for a fixed price and the other party's bid was for either a fixed price or, in the alternative, a price equal to $\$ 101,000$ more than the other bid. It was held that the invitation had created a fixed bidding sale and that, therefore, Royal Trust was not entitled to accept a referential bid, being a bid expressed as a certain sum in excess of the highest fixed bid.

\section{H. BANCORP FINANCIAL LIMITED v. DARWAI INVESTMENT CORPORATION ${ }^{2}$}

Darwai granted a mortgage to Bancorp of property which was later sold to Taproot Investments Ltd. The mortgage secured the sum of $\$ 1,500,000$ but at the time of the sale, only $\$ 165,000$ had been advanced. Taproot assumed the mortgage pursuant to an agreement with Bancorp. Darwai was not a party to the assumption agreement and was not expressly released from the mortgage. Taproot defaulted under the mortgage.

\footnotetext{
20. [1957] 1 Q.B. 267 at 288.

21. (1985) 61 N.R. 215 (H.L.).

22. (1985) 61 B.C.L.R. 130 (B.C.S.C.).
} 
Bancorp foreclosed on the mortgage and sued Darwai for the deficiency remaining after the foreclosure.

Darwai argued that there had been a complete novation of Taproot into the mortgage resulting in a release of Darwai.

The Court distinguished the present case from those in which it was held that no novation had occurred, on the basis that at the time of the assumption of the mortgage, only $\$ 165,000$ had been advanced. The balance of the total principal amount of $\$ 1,500,000$ was advanced thereafter to Taproot. The Court held that a novation had occurred with respect to that unadvanced balance, but that Bancorp was still entitled to recover $\$ 165,000$ from Darwai.

Darwai argued that proceeds of the foreclosure should be applied to repayment of the first sums advanced, being the $\$ 165,000$ advanced to them. In support of this proposition, Clayton's Case ${ }^{23}$ was cited. The rule in Clayton's Case is that a debtor has the first right to appropriate payments to any debt he may owe to the creditor; if he does not do so, the creditor has the right to appropriate. Where there is a continuous account with debits and credits entered and no express appropriation is made, in the absence of contrary evidence, the law presumes that the parties intend that the payments be appropriated to the older debts. Where book entries are not communicated to the debtor by the creditor, the creditor is not prevented from making an express appropriation at any time.

Since there was no statement of account, which was necessary for the presumption to arise, the presumption did not arise. The proceedings themselves constitute an election by Bancorp not to appropriate the foreclosure proceeds to the first $\$ 165,000$, which is an election it is entitled to make. Bancorp obtained judgment against Darwai for $\$ 165,000$.

\section{NORCEN INTERNATIONAL LTD. v. SUNCOR INC. ${ }^{24}$}

The trial decision and the facts in this case were reviewed in the 1985 edition of this paper. ${ }^{2 s}$

The appeal of Norcen was allowed in part. Norcen was held to be entitled to its royalty in respect of petroleum compensation payments received by Suncor for periods prior to July 7, 1982, which payments ought to be characterized as a part of the price received by Suncor. Production shipped from the Suncor plant was deemed by the legislation and regulations to have been imported, and the first user of this production was deemed to be an importer entitled to apply for compensation payments. The user's entitlement to petroleum compensation payments was conditioned upon his payment of the full purchase price. The Court considered it to be immaterial that some of the petroleum compensation payments were paid directly to Suncor rather than to the user.

However, for the period commencing on July 7, 1982, the governing law was quite different. By virtue of amendments to the legislation and regulations, Suncor was prohibited from selling its production at a price

23. (1816) 1 M.E.R. S72, 35 E.R. 781.

24. (1986) 44 Alta. L.R. (2d) 145.

25. (1985) 24 Alta. L. Rev. 143 at 152. 
[VOL. XXV, NO. 1

higher than the regulated price. To the extent that it received compensation over and above the regulated price, such compensation could not be considered to form part of the "price received".

\section{J. RENAISSANCE RESOURCES LTD. v. METALORE RESOURCES LTD. ${ }^{26}$}

The trial decision and the facts of this case were reviewed in the 1984 edition of this paper. ${ }^{27}$ The Court of Appeal dismissed the appeal by Metalore Resources Ltd.

\section{MORTGAGES}

\section{A. RE CAISSE POPULAIRE DE MILLARDVILLE CREDIT UNION $A N D B U T T^{23}$}

The mortgagor granted a first mortgage to the appellant credit union in 1979. This mortgage, which was registered, contained a provision whereby the mortgagor agreed not to make any further mortgages of the subject lands without the consent of the mortgagee.

In 1980, without having obtained the consent of the first mortgagee, the mortgagor granted a second mortgage of the land to the respondent bank. Subsequent to the granting of the second mortgage, the first mortgage was renewed on two occasions with increases in the interest rate. The renewals and increases were contained in extension agreements which were not registered and of which the second mortgagee was unaware.

The Court held that while the second mortgagee has notice of the first mortgage and of the provision prohibiting subsequent mortgages, it was not under any obligation to notify the first mortgagee that it was taking a second mortgage. The second mortgagee did not induce a breach of the first mortgage. The Court further held that the extension agreements would not have entitled the first mortgagee to the higher rates of interest in priority to the second mortgagee if registered, being subsequent in time to the second mortgage, and thus could not have that effect if unregistered.

\section{TRUSTS AND FIDUCIARY DUTIES}

\section{A. RE ONTARIO SECURITIES COMMISSION AND GREYMAC CREDIT CORP.}

Greymac Credit Corporation held bank accounts in its name at Greymac Trust Company and Crown Trust Company. The receiver of Greymac Credit sought directions as to the distribution of the funds in such accounts among various creditors of Greymac Credit.

Greymac Credit had received the proceeds of the foreclosure of a mortgage held in its name. The mortgage had been syndicated by Greymac Credit to various investors, including itself (the "Participants"). Pursuant to a written agreement, Greymac Credit had acknowledged that it held the

26. (1985) 38 Alta. L.R. (2d) 133, [1985] I W.W.R. 673.

27. (1984) 23 Alto. L. Rev. 183 at. 195.

28. (1985) 19 D.L.R. (4th) 188 (B.C.C.A.).

29. (1985) 19 D.L.R. (4th) 470 (Ont. H.C.J.). 
mortgage in trust for the Participants. The Court found that the foreclosure proceeds were also held by Greymac Credit in trust for the members of the syndicate. Part of the mortgage proceeds were distributed to the Participants. It is implicit in the decision that a term deposit at The Royal Bank in an amount equal to the balance of the foreclosure proceeds was held in trust by Greymac Credit for the Participants. The term deposit was subsequently cashed and the proceeds deposited in an account in Greymac Credit's name at The Royal Bank which already had money in it. On the same day an amount equal to the term deposit was transferred from the Royal Bank account to Greymac Credit's account at Greymac Trust. That account already had funds deposited in it which, the Court found without explanation, were beneficially owned by three other companies (the "Companies"). The Court traced the Participants' funds from the term deposit to The Royal Bank to the Greymac Trust account, finding that the funds transferred from The Royal Bank to Greymac Trust were beneficially owned by the Participants and that, after the transfer, the funds on deposit at Greymac Trust were beneficially owned by the Participants (one of whom was Greymac Credit) and by the Companies. Various deposits from and withdrawals to the Greymac Trust account were made by Greymac Credit. Withdrawals exceeded deposits. Thereafter, four million dollars were transferred from the Greymac Trust account to an account in the name of Greymac Credit at Crown Trust. Thereafter, various withdrawals were made from the account at Greymac Trust but there was no activity in the Crown Trust account. At the time of the trial, the total amount in the two accounts was less than the amount required to be held in trust for the Participants and the Companies.

The Court made the following findings:

1. it is proper to apply the rule in Re Hallett's Estate, ${ }^{30}$ which is that when a trustee commingles funds held by it in trust with its own funds and then dissipates the mingled account (i.e. by withdrawals which cannot be traced), the amounts dissipated are allocated first against his own funds and only to the trust funds after all of his own funds have been used, on the presumption that the trustee would expend its own funds before expending the trust funds;

2. it is not appropriate to apply the rule in Clayton's case, ${ }^{31}$ because the rule is unfair, the rule in Clayton's case being that when a trustee commingles funds held by it in trust with other funds held by it in trust and then dissipates the mingled account, the amounts dissipated are allocated to the trust funds on a "first in first out" basis so that the dissipation is allocated to the trust funds in the chronological order in which they were obtained;

3. the rule in Clayton's case is based upon the presumed intention of the trustee first to dissipate trust funds which it has held for the longest time and it is more sensible and equitable to presume that the trustee would dissipate trust funds pro rata on the basis of the proportions which the amounts of the trust funds bear one to the other at the time that the dissipation occurs; and

30. (1879) 13 Ch. D. 696.

31. Supra n. 23. 
[VOL. XXV, NO. 1

4. the account at Crown Trust was traceable, so that the funds deposited therein were owned in the same proportions as the funds in the Greymac Trust account were owned immediately prior to the transfer of funds from Greymac Trust to Crown Trust.

\section{B. STANDARD INVESTMENTS LTD. v. CANADLANIMPERIAL BANK OF COMMERCE 32}

This was an action for damages for an alleged breach of fiduciary duties owed by the defendant bank to the plaintiffs.

In the early 1970's, the plaintiffs decided to attempt to acquire control of Crown Trust and further decided that they would require the assistance, advice and financial support of the defendant to do so. In order to strengthen their relationship with the defendant, they transferred their banking business to the defendant. The defendant was aware of the business opportunities available to it through other trust companies controlled by the plaintiffs.

The plaintiffs asked for a meeting with the president of the defendant to obtain his advice and, at that meeting, divulged the name of Crown Trust. The president of the defendant undertook to arrange an introduction to a director of the defendant who was influential with the controlling shareholders of Crown Trust and indicated that he would do everything he could to assist the plaintiffs.

Unknown to the plaintiffs, the chairman of the defendant, around the same time, at the request of the aforementioned bank director, had agreed to cause the defendant to purchase shares of Crown Trust in order to prevent the plaintiffs from acquiring control of the company and later agreed not to sell its $10 \%$ block of Crown Trust otherwise than in concert with the controlling shareholder.

The Court concluded that the president and chairman of the defendant, and their successors, were the directing minds of the defendant with respect to the defendant's activities in relation to the plaintiff's efforts to obtain control of Crown Trust and, as well, Crown Trust's attempts to resist those efforts.

The Court held that, in certain circumstances, a fiduciary relationship may be created between a bank and its customer and that, in this case, such a relationship was created. The plaintiffs had shown that the relationship between the plaintiffs and the defendant had "crossed the line of that of a mere debtor-creditor relationship to that of a fiduciary relationship". The Court cited, with approval, passages from Lloyd's Bank Ltd. v. Bundy, ${ }^{33}$ where it was said that fiduciary relationships between a bank and its customers arise where the customer relies on the guidance or advice of the banker, the banker is aware of that reliance and the banker obtains or may obtain a benefit from the transaction; in addition, confidentiality must be shown to exist. 
The Court found that the plaintiffs were relying on the advice and guidance of the bank, that the bank was aware of this reliance, and that the bank obtained a benefit through increased business. The disclosure by the plaintiffs of their intentions with regard to Crown Trust created the necessary "confidential relationship".

The Court found that the bank had a duty, at minimum, to advise the plaintiffs with reasonable care and skill and, more importantly, to disclose to the plaintiffs the conflict of interest which existed with respect to Crown Trust. If the bank could not reveal the conflict because of some duty of confidentiality to others, it was at least under an obligation to advise the plaintiffs that it had a position adverse to their plans or that it had a conflict of interest, or to have simply refused to give advice and assistance to the plaintiffs.

The Court held that the bank breached the duty by failing to disclose this conflict, by the subsequent advice and assistance given to the plaintiffs and by the later sale of its shares in Crown Trust.

The plaintiffs were held to be entitled to damages equal to the difference between the return which they would have received by investing the money which had been invested in Crown Trust shares in treasury bills and the value of the shares.

\section{RE LIBERAL PETROLEUMS TRUST ${ }^{34}$}

Under the terms of a trust deed, the trustee was to distribute to the beneficiaries the net proceeds from the sale of oil and gas production from certain lands after deducting its fees and all taxes imposed on the beneficiaries.

The Income Tax Act ${ }^{33}$ provides for the taxation of "designated income" of a trust in the hands of the trustee where the trust has non-resident beneficiaries.

The Court held that the tax on designated income should be borne rateably by all of the beneficiaries, notwithstanding that not all of the beneficiaries were non-residents of Canada. The trustee of the trust is required to administer the trust without favour for or prejudice against any class of beneficiaries. The equitable rule of apportionment, which is not a rule of law, and which provides that the nature of any burden imposed on trust property will determine whether it is borne by the life tenant or the remaindermen, applies only where property is held in trust for several persons in succession. Egbert $J$. declined to extend this rule to the present case, while acknowledging that the result reached in this case might be inequitable.

\section{BANK OF MONTREAL v. R. \& R. ENTERTAINMENT LTD. ${ }^{36}$}

This was an action by the plaintiff bank against the defendant corporation as the maker of a promissory note and against the individual defendants, who were guarantors of the corporation's debts to the bank.

34. (1985) 64 A.R. 243 (Alta. Q.B.).

35. S.C. $1970-71-72$, c. 63.

36. (1984) 27 B.L.R. 159 (N.B.C.A.). 
The corporate defendant maintained two accounts with the bank, one of which was called a "trust account". A credit balance in one bank account was regularly used to offset an overdraft in the other.

The bank had dishonoured cheques drawn on the trust account and setoff the "trust account" balance against the operating account overdraft. The Court concluded that the "trust account" was not a true trust account and that the company was not a trustee for entertainment promoters, but rather merely a debtor for the proceeds of the sale of tickets. If the account was a true trust account, the bank would have had no right of set-off.

\section{E. HALIFAX INSURANCE CO. v. CANADIAN IMPERIAL BANK OF COMMERCE ${ }^{37}$}

An insurance agency received insurance premiums pursuant to an agency contract, which obligated the agent to hold the premiums as trust funds. These funds were deposited in a branch of the defendant in an account referred to as a trust account. The bank had notice of the nature of the funds. The bank removed the funds from the trust account and applied them against indebtedness owing by the agent to the bank. The premiums were, from time to time, utilized for operating purposes by the agent without the plaintiff's knowledge and contrary to the terms of the agency contract. It was held that the funds were the property of the plaintiff, that they were held by the agent in trust for the plaintiff, that they could be traced to the bank and that they were held by the bank as a constructive trustee for the plaintiff.

\section{F. INTERNATIONAL CORONA RESOURCES LTD. v. LAC MINERALS LTD..$^{38}$}

Corona and Lac were involved in the gold mining business. Corona had caused some diamond drilling to be done on claims which it owned in northern Ontario which established the likelihood of a commercial gold mining development. Corona published its results which came to the attention of Lac. Lac contacted Corona, following which Lac's geologists visited the Corona claims and discussed Corona's exploration program with Corona's geologists. There was an exchange of correspondence between Lac and Corona and various meetings, the purpose of which was to explore the possibility of forming a joint venture or making another arrangement whereby Lac and Corona could jointly exploit Corona's discovery.

It was clear that the deposit Corona had discovered extended to certain adjoining lands which had previously been staked and were known as the "Williams' claims". Early on in its involvement in the play, Corona concluded that it should attempt to acquire the Williams' claims. Prior to being contacted by Lac, Corona attempted to contact the owners of the Williams' claims with a view to acquiring them. During the period in which Corona and Lac were in communiction over the exploration program and the possibility of forming a joint venture or other arrangement, Corona

37. (1984) 28 B.L.R. 135 (NIld. S.C.T.D.).

38. (1986) 53 O.R. (2d) 737 (Ont. H.C.J.). 
was pursuing acquisition of the Williams' claims and this was disclosed to Lac by Corona. Lac also made an offer to acquire the Williams' claims without informing Corona and ultimately obtained the Williams' claims.

Corona brought this action claiming (a) breach of contract, (b) breach of confidence, and (c) breach of fiduciary duty.

The Court found that there was no contract between Lac and Corona and rejected the first claim.

The Court allowed Corona's claim under breach of confidence and breach of fiduciary duty. As a preliminary matter, the Court found that there is no accepted practice in the mining industry which imposes a restriction on a visitor to a field site. However, the Court found that there is a practice in the mining industry that imposes an obligation upon parties when they are seriously negotiating not to act to the detriment of each other.

The Court stated that there are three elements to a breach of confidence action. There must be information which has a necessary quality of confidence about it; that information must be communicated in circumstances in which an obligation of confidence arises; and there must be an unauthorized use of the information to the detriment of the disclosing party. The Court found that although some of the information disclosed by Corona to Lac was public, some of it was not and that some of the nonpublic information was of great use to Lac in evaluating the Williams' claims. Since the information was disclosed to Lac in the course of negotiations and was obviously confidential, it was disclosed in circumstances giving rise to an obligation of confidence. There was an unauthorized use of the information because it assisted Lac in evaluating the Williams' claims and ultimately acquiring them. The Court found that if Lac had not obtained the Williams' claims, then Corona most probably would have.

The Court found that as a result of the negotiations towards a joint venture or some other business relationship, Lac and Corona owed fiduciary duties to each other to act fairly and not to act to the detriment of each other. Lac was in breach of those duties by acquiring the Williams' claims.

In awarding a remedy to Corona, the Court noted that damages for a breach of fiduciary duty are not determined on the basis of the plaintiff's loss but rather on the basis of the defendant's gain. Further, the obligation of a defaulting trustee or fiduciary is essentially one of effecting restitution to the estate. The equitable obligation of restitution is of a more absolute nature than a common law obligation to pay damages. Accordingly, the Court ordered Lac to transfer the Williams' claims to Corona.

Lac had spent $\$ 200,000,000$ in developing the Williams' claims. Section 37(1) of the Conveyancing and Law of Property Act, ${ }^{39}$ provides that:

Where a person makes lasting improvements on land under the belief that it is his own, he or his assigns are entitled to a lien upon it to the extent of the amount by which its value is enhanced by the improvements....

39. 'R.S.O. 1980 , c. 90. 
[VOL. XXV, NO. 1

Corona argued that that provision was not applicable in this case because, at all material times, Lac was aware of Corona's claim and, therefore, Lac did not believe that it owned the claims. The Court rejected that argument, finding it difficult to believe that Lac would have expended such a large sum of money without truly believing that it owned the property. Accordingly, the Court granted a lien to Lac on the claims. The lien was for the value of the enhancement of the claims resulting from Lac's actual expenditures. That value was $\$ 50,000,000$ less than Lac's expenditures, because the claims would have been developed less extensively by Corona if Corona had acquired the Williams' claims, because of Corona's activities on the adjoining lands.

The Court also calculated the damages which it would have awarded if a transfer of the Williams' claims was not appropriate. Damages were calculated not as of the date of the breach by Lac but as of the date of the action. Since the claims had been substantially developed between those dates, that finding greatly increased the amount of damages. The Court stated that the appropriate method for calculating damages was on the basis of discounted estimated cash flows from the development of the claims. Rule 53.09 of the Ontario Rules of Court provides that a discount rate of $2.5 \%$ should be used in determining the amounts of awards in respect of future pecuniary damages. The Court stated that this discount rate is based on the historical average difference between the return on safe investments and the rate of inflation. The Court found, however, that because the cash flow from a gold mine is subject to risks not associated with government bonds or other safe investments, Rule 53.09 was not appropriate in this case. The Court applied a risk factor to account for the uncertainties as to the quantities of gold that would be recovered from the claims and the price which could be received therefor. The result was that the estimated future cash flow was discounted at $4.5 \%$, a rate which would seem very low to those familiar with the oil and gas industry.

Lac also contended that in calculating discounted cash flows, account should be taken of the fact that Corona had offered to pay a 3\% net smelter return to the previous owner of the Williams' claims, while Lac had negotiated an arrangement whereby only a $1.5 \%$ net smelter return was being paid. The Court rejected that argument on the basis that the proper method of assessing damages is according to the defendant's gain and not according to the plaintiff's loss. Accordingly, the $1.5 \%$ net smelter return was applied in determining the estimated future cash flows. The Court did, however, reduce the damages by its estimate of income taxes which would have been paid by Lac had Lac retained the property. The pre-income tax discounted cash flow was approximately $\$ 900,000,000$ and the after-tax estimated future cash flow was approximately $\$ 500,000,000$. Because of uncertainties, however, the Court set damages at $\$ 700,000,000$. The Court also ruled that an accounting should be made to determine the profits which had been made by Lac from the property prior to the date of the judgment. 


\section{LAND TITLES AND REAL PROPERTY}

\section{A. PARAMOUNT LIFE INSURANCE COMPANY v. HILL}

The signature of the defendant was forged on an interim agreement for the sale of the matrimonial home and on a commitment letter addressed to the mortgagee of the purchaser.

The Court held that the mortgage was null and void. Lomas J. distinguished the case from two earlier decisions. The basis for the distinction between the present facts and those two cases was that in both of the earlier cases the lenders were contracting with persons in whose names certificates of titles had issued but had no knowledge of the fraud in which those persons had participated. Thus, the lenders were relying on the register. In this case, the mortgagee did not rely on a certificate of title issued in the purchaser's name, because title had not been transferred to the purchaser when the mortgagee dealt with the purchaser. The Court cited the following passage from Gibbs v. Messer:"1

The protection which the statute gives to persons transacting on the faith of the register is ... limited to those who actually deal with . . . a proprietor whose name is upon the register. Those who deal ... with a forger . . . do not transact on the faith of the register . . - although the fact of their being registered will enable them to pass a valid right to third parties....

\section{B. WYO-BEN, INC. v. WILSONMUD CANADA LTD..$^{42}$}

The plaintiff had delivered chemicals to two adjoining parcels of land, on which were located a total of three wells. The pool underlying the two parcels of land was connected. The plaintiff registered a lien in respect of the purchase price for all of the chemicals against only one of the parcels.

The Alberta Court of Appeal held that the lien claim in respect of the liened parcel was valid, notwithstanding that some of the chemicals were used in a well not located on that parcel. The Court held that the "land" in respect of which the well was drilled could include land other than that on which the well was located, i.e. land which the owner intended the work or improvement to benefit and which actually did benefit from the material supplied.

The Court was of the view that this more generous interpretation should be applied in view of the object of the statute, which is to secure payment to workmen and suppliers for work and materials which improve land.

\section{PARTNERSHIPS AND JOINT VENTURES}

\section{A. VOLZKE CONSTRUCTION LTD. v. WESTLOCK FOODS LTD. ${ }^{3}$}

The plaintiff general contractor had contracted with the $80 \%$ owner of a shopping mall for the construction of additions thereto. He sought to recover the unpaid portion of the cost of the additions from the $20 \%$ owner

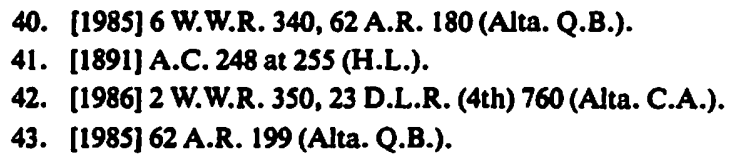

40. [1985] 6 W.W.R. 340, 62 A.R. 180 (Alta. Q.B.).

41. [1891] A.C. 248 at 255 (H.L.).

42. [1986] 2 W.W.R. 350, 23 D.L.R. (4th) 760 (Alta. C.A.).

43. [1985] 62 A.R. 199 (Alta. Q.B.). 
of the shopping centre. The $20 \%$ owner was not a party to the construction contract. However, the $20 \%$ owner and the $80 \%$ owner had jointly and severally issued a debenture to a lender and subsequently jointly and severally covenanted to repay a loan secured by a mortgage on the property. The contractor alleged that, on the evidence, the $20 \%$ owner and the $80 \%$ owner were the members of a partnership and that the $20 \%$ owner was, therefore, liable for the unpaid cost of the improvements.

The Court stated that joint ownership of property does not of itself create a partnership with respect to the property, even though the coowners may share the profits of ownership.

In this case, the $80 \%$ co-owner was responsible to make the development arrangements and it did so in its own name. The defendant was merely the co-owner of an undivided $20 \%$ interest in the land. The Court found that there was no evidence of mutual control and management of the enterprise by the co-owners. The $20 \%$ owner was not liable to the contractor.

The decision may be applicable to the situation where an operator enters into a drilling contract with a drilling contractor and becomes insolvent before the drilling contractor is paid. This case may support the proposition that the non-operators having interests in the well would not be contractually bound to pay the drilling contractor.

\section{B. NUFORT RESOURCES INC. v. EUSTACE; HARQUAIL v. CONSOLIDATED MONTCLERG MINES LTD."}

This case deals with the fiduciary duties of stockbrokers, lawyers, directors and joint venturers. It involved a joint venture created to revive and refinance a defunct mining company owning mining claims adjacent to those of one of the corporate participants in the joint venture. The joint venture was disbanded when the members reached an impasse regarding the percentage interest of one of their number, who was a plaintiff and a principal of the other plaintiffs in the actions. One of the members of the joint venture was a stockbroker, whose firm underwrote a rights offering by the defunct company. Another of the principals was a solicitor who acted on behalf of the joint venturers in making a proposal to the principals of the defunct company and who was also a director of one of the plaintiff corporations which was a member of the joint venture.

The Court stated that upon the dissolution of a partnership, in the absence of an agreement to the contrary, there is no rule that the former partners cannot make use of information acquired by them in the course of the partnership, and do so in competition with each other. Thus, the joint venturers were at liberty to compete with each other in respect of the venture for which the joint venture had existed. The Court found in the present case that there was no bad faith on the part of the defendants.

The Court further held that there had been no misuse of information which could be considered to be confidential according to law. It followed the Alberta Court of Appeal decision in Ridgewood Resources Ltd. v. Henuset, ${ }^{45}$ where it was held that disclosure of information in the public

44. (1985) 29 B.L.R. 282 (Ont. H.C.J.).

45. (1982) 18 Alta. L.R. (2d) 68, 35 A.R. 493 (Alta. Q.B.). 
domain could not produce a confidential relationship, notwithstanding the circumstances of the disclosure, which would make the recipient liable for subsequent use thereof.

The Court then turned to a consideration of the duties owed by the defendant Eustace as a solicitor to certain of the plaintiffs. The Court was troubled by the different roles that this defendant had played during the course of the events which were the subject of the litigation, but held that no obligation for restitution arose, since all of the participants in the joint venture had been aware of the fact that Eustace was a principal in the transaction and that his capacity as solicitor was limited to the negotiation, preparation and submission of a proposal to the principals of the defunct company. The Court distinguished this situation from one where a solicitor, being a stranger to the transaction, and having been retained by one of the principals therein, subsequently seeks to appropriate the transaction for his own benefit, and from the situation where a solicitor was on a general continuing retainer. Eustace was not in receipt of information beyond that of any of the other principals in the transaction and was thus not subject to any greater disability than that to which the other members of the joint venture were subject.

The Court also considered the duties of Eustace as a director of the plaintiff Nahanni. The Court concluded that this plaintiff had not established a breach by Eustace of his duty as a director. It was considered to be significant that there was no assurance that the defunct company, if reactivated, would develop its properties and, in fact, by the time of the trial it had not done so. The Court also noted that Nahanni's aspirations to develop the defunct company's properties were not precluded by the termination of the joint venture. There was no evidence that Nahanni had made any effort to pursue the development.

It should be noted that the Court rejected the defence contention that because Eustace was a "rubber stamp nominee" director he was, therefore, not burdened with the obligations which the law would otherwise impose upon a director.

\section{MOLCHANv. OMEGA OIL \& GAS LTD. ${ }^{45}$}

The trial decision and the facts in this case were reported in the 1984 edition of this paper."

The basis upon which the trial decision was reached, that the general partner had caused the limited partnership to do an act which prevented it from carrying on the limited partnership's business, without the unanimous consent of the limited partners, was not dealt with in the reasons for judgment in the appeal decision, which overturned the trial decision.

The case was disposed of by the Court of Appeal on the basis that the relationship between the parent company and its subsidiary, the general partner of the limited partnership, and a common director, was one which gave rise to various conflicts of interest, the result being that a fiduciary 
duty was imposed. It found, however, that this fiduciary duty, which required the various parties to have regard to the interests of the others and to discharge their duties in good faith, was not breached.

\section{BUSINESS CORPORATIONS}

\section{A. CANADIAN GAS \& ENERGY FUND LTD. v. SCEPTRE RESOURCES LTD. (formerly known as Francana Oil \& Gas Ltd.) \&}

This was an application by the plaintiffs to have the court fix the fair value of their shares in Francana Oil \& Gas Ltd. pursuant to section 184 of the Canada Business Corporations Act. ${ }^{\star}$

On a consideration of the purpose and intent of section 184 , namely that a minority shareholder is entitled to be bought out in the event that the economic nature of his investment changes fundamentally without his consent, the Court held that the payment of fair value pursuant to section 184 is to be in cash.

One of the issues considered by the Court was the method to be utilized in determining the fair value of the dissenters' shares. The Court considered it sigmficant that the shares in question-were those of a public company, widely held and actively traded. Evidence heard in Court regarding value disclosed that numerous and variable assumptions as to the value of oil and gas assets had a considerable impact upon each determination and that stock market value most realistically reflected fair value. The Court considered the market price immediately preceding the announcement as well as the pattern of the stock market generally in the following months.

\section{FOREIGN INVESTMENT}

\section{A. CANADA v. FALLBRIDGE HOLDINGS LTD, and CENTRAL CARTAGE CO. ${ }^{\circ 0}$}

This case involves several issues relating to the interpretation of the Foreign Investment Review Act." In light of the repeal of that statute and the generally complicated nature of the case, we do not propose to set out the facts in detail, but simply to discuss briefly one of the issues which was raised before the Court.

That issue was whether Fallbridge Holdings Ltd., which was a Canadian-controlled entity, and Canadian Cartage Co., a non-eligible person, formed a "group of persons" as that phrase is used in subsection 8(1) of the Act.

The two companies had acted in concert to effect the acquisition of a Canadian business enterprise, the objective being that Central Cartage Co. would acquire the American half of the Ambassador bridge between Detroit and Windsor and Fallbridge would acquire ownership of the Canadian half of that bridge. The Court found that this was a joint

48. (1985) 29 B.L.R. 178 (AIta. Q.B.).

49. S.C. $1974-76$, c. 33.

50. (1985) 63 N.R. 17 (F.C.A.).

51. S.C. $1973-74$, c. 46. 
activity, and also referred to the fact that Central Cartage Co. financed the purchase by Fallbridge. Therefore, Fallbridge and Central Cartage Co. were a group of persons, one of whom was a non-eligible person, who acted in concert in acquiring control of a Canadian business enterprise.

The Court also considered the question of extra-territorial jurisdiction and applied the Federal Court Trial Division decision in Dow Jones \& Co. Inc. v. Attorney General of Canada, ${ }^{2}$ where it was held that the application of the Act to the change of control of a Canadian business enterprise, upon the sale of its foreign controlled parent to another non-eligible person, did not amount to extra-territorial application. The Act applied only to the acquisition of control of a business carried on in Canada and the Act was being enforced in respect only of that business. Similar reasoning applies in the case of Central Cartage Co., a Michigan corporation. In this case, the agency seeks only to regulate the acquisition of control of a Canadian business, being the operation of the Canadian half of the Ambassador bridge, by persons other than Canadians.

\section{TAXATION}

\section{A. CANPAR HOLDINGS LTD. v. GOVERNMENT OF SASKATCHEWAN $" 3$}

The Saskatchewan Oil Well Income Tax Act, ${ }^{54}$ imposes a tax on oil well income. The Act provides that in computing oil well income, a taxpayer is entitled to deduct "any amount paid or payable ... . on account of ... . any royalty, and any other payment in the nature of a royalty ...". Canpar sold a net profits interest to Provo Gas Producers Limited in 1979. That agreement provided that Canpar would pay to Provo, each month, a percentage of the net profits from its oil and gas operations. Also in 1979, Canpar entered into an agreement with Dome Petroleum Limited whereby, in consideration of Dome paying a disproportionate share of costs on jointly owned oil and gas properties, Canpar agreed that Dome would be entitled to a percentage of the "Net Proceeds of Production" from Canpar's interests. The issue in the case was whether or not the net profits payments to Provo and the net proceeds of production payments to Dome were payments of a royalty or payments in the nature of a royalty for purposes of the Oil Well Income Tax Act.ss

The Court referred to two alternative definitions of the term royalty which had been judicially approved, one being payments "payable for the right to explore for, bring into production and dispose of the oils or minerals yielded up" and the other being payments "for the right or privilege of taking oil or gas out of a designated tract". The Court found that the net proceeds of production payments to Dome were payable in consideration of obligations assumed by Dome and the net profits interest payments to Provo were payable in consideration of an amount paid by Provo to Canpar. In both circumstances, the payments did not fit within

52. (1980) 113 D.L.R. (3d) 395 (F.C.T.D.).

53. (1985) 39 Sask. R. 12 (Q.B.).

54. R.S.S. 1978 (Supp), c. O-3.1.

55. Id. 
[VOL. XXV, NO.1

either of the definitions of royalties referred to by the Court. The Court also noted that the payments to Dome and Provo were "not expressed on the basis of the production or use of the mine or well". The payments were stated to be expressed in terms of a fund.

Canpar also argued that the payments to Dome and Provo were not Canpar's income and, therefore, Canpar was not obligated to pay tax thereon under the Act. On that basis, for purposes of the Act, the payments would have been considered as income of Dome and Provo, who would have been liable for tax thereon. The Court rejected that argument stating that it had no merit.

\section{B. PETRO-CANADA INC. v. DEPUTY MINISTER OF NATIONAL REVENUE FOR CUSTOMS AND EXCISE \$}

Petro-Canada operated a miscible flood scheme whereby natural gas was injected at high pressure into oil pools to enhance recovery of the oil. Petro-Canada took delivery of natural gas for use in the injection scheme at a metering station twelve miles from the injection station. Petro-Canada installed booster compressors at the delivery point to increase the pressure of the gas to facilitate movement in Petro-Canada's pipeline from the delivery point to the injection station. The Excise Tax Acts imposes a tax on the sale of goods purchased or manufactured in Canada other than "machinery and apparatus ... for use ... directly in the manufacture or production of goods". Petro-Canada appealed the decision of the Tariff Board that the booster compressors were not exempt from the sales tax. The issue in the case was whether or not the booster compressors were used directly in the manufacture or production of goods. It was conceded that the compressors are machinery and apparatus and that the production of oil is the production of goods. The Court found that the fact that the booster compressors did not change the gas but only its pressure was not sufficient reason to state that they were not used in the production of oil. The Court reversed the decision of the Tariff Board and declared the boosters to be exempt from the excise tax.

\section{DEPUTY MINISTER OF NATIONAL REVENUE FOR CUSTOMS AND EXCISE v. AMOCO CANADA PETROLEUM COMPANY ${ }^{\mathrm{S}}$}

This decision considered whether a pipeline used to transport natural gas liquids to a fractionation plant was exempt from tax under the Excise Tax Act' by virtue of being machinery and apparatus used directly in the manufacture or production of goods. It was agreed that the production of natural gas liquids in the fractionation plant was the manufacture or production of goods for purposes of the exemption contained in the Act. It was contended that since the pipeline had nothing to do with a change in the nature, form or quality of the goods, the pipeline was not directly used in the production of goods as required by the terms of the exemption

56. (1985) 60 N.R. 111 (F.C.A.).

57. R.S.C. 1970 , c. E-13.

58. (1985) 63 N.R. 303 (F.C.A.).

59. Supra n. 57. 
provision. The case turned upon the meaning of the word "directly". The Court found that the Tariff Board was not demonstrably in error in finding that the pipeline was used directly in the production of goods and, therefore, exempt from tax.

\section{SALE OF LAND}

\section{A. SELKIRK PETROLEUM LTD. v. DRUMMOND OIL \& GAS LTD. AND MIDALE PETROLEUMS LTD..$^{\circ}$}

In 1980, pursuant to a written agreement, West Central Resources Ltd. sold, inter alia, a $12.5 \%$ interest in two freehold petroleum and natural gas leases referred to as the "Weyburn Leases" to Selkirk. Prior to the sale, West Central had held a 25\% working interest in the Weyburn Leases. No formal documentation evidencing the sale was prepared.

In January, 1981, Drummond Petroleum Ltd. acquired all of the shares of West Central. The Share Acquisition Agreement included a schedule describing West Central's assets which stated that West Central held a $12.5 \%$ interest in the Weyburn Leases. West Central and Frio Oil Ltd. amalgamated in September, 1981 and the amalgamated company changed its name to Drummond Oil and Gas Ltd. in October of that year.

In a letter dated February 3, 1982 Drummond Oil and Gas Ltd., Midale and certain other parties, not including Selkirk, confirmed that Drummond and such other parties were selling a $100 \%$ interest in the Weyburn Leases to Midale. The agreement indicates that Drummond had a $25 \%$ interest in the Weyburn Leases, the interest which it would have had it if had not sold any interest to Selkirk.

The plaintiff sued Midale and Drummond. At trial, it abandoned its claim against Midale because Midale was a bona fide purchaser for value without notice.

The Court found that West Central had agreed to provide Selkirk with documents of title respecting its interest. When Drummond Petroleum acquired West Central, it assumed, in law, all of the obligations of West Central. The Court found that the obligation to provide Selkirk with documents of title had been breached and awarded damages to Selkirk.

In assessing damages, the Court ruled that since the cause of action was a breach of contract and not a breach of trust, the proper date for assessing damages was the date of trial, being February, 1986. An economic evaluation of the wells located on the Weyburn Leases had been made in September, 1985. The Court held that because of the drop in oil prices since January 1,1986 , it was required to "arbitrarily discount" the evaluation by $30 \%$. The Court also awarded Selkirk damages for production which had been taken and sold prior to December 31, 1985. The Court did not have any evidence as to production after that date.

Drummond counterclaimed for recovery of costs (including legal costs) incurred by it to maintain and defend title to certain leases, interests in which had been sold to Selkirk by West Central. Although Selkirk was never consulted with respect to those costs, the Court ruled that Selkirk

60. Unreported, 7 April 1986, No. $8401-19438$ (Alta. Q.B.). 
was responsible for its share of such costs since "the plaintiff cannot have it both ways, on the one hand saying that its interest in all the properties was wrongfully sold and, on the other hand, saying that it is not responsible for the cost of maintaining and protecting those properties". Selkirk had sold its interest in certain of the leases to a partnership of which the former principals of West Central were partners. The Court found that West Central's records contained sufficient information to disclose that sale to Drummond, so that Drummond knew or should have known that Selkirk had sold its interest. Selkirk was not responsible for the costs associated with such leases.

The decision does not disclose the state of registrations in respect of the Weyburn Leases. It is not clear if Midale, West Central or Drummond had registered interests or had filed caveats. The decision does not consider whether or not Drummond could legally sell to Midale an interest which Drummond did not own. It is submitted that the failure of West Central and Drummond to provide Selkirk with conveyancing documents did not prevent Selkirk from filing a caveat to protect its interest. At best, we believe that Selkirk could have argued that Drummond held Selkirk's interest in trust for Drummond and that Drummond breached that trust by selling Selkirk's interest to Midale. If the decision had been based on a breach of trust, the damages awarded to Selkirk would have been different. The action pertained to lands located in Saskatchewan but was brought in Alberta. The Alberta Court may not have had jurisdiction to determine ownership priorities between Selkirk and Midale.

\section{B. MONASHEE PETROLEUMS LTD. v. PAN CANA RESOURCES LTD. ${ }^{61}$}

Pursuant to a Conveyance Agreement dated February 13, 1970, the plaintiff sold an interest in six producing oil wells and 15 undrilled spacing units to a predecessor of the defendant. The case concerned the interpretation of the following two provisions of the Conveyance Agreement:

1. A covenant by the purchaser to drill three wells on the undrilled spacing units "provided, that no working interest partner refuses to consent to the drilling of such wells (which refusal will only relieve the Assignee of the obligation to drill the particular well to which such consent is so refused)".

2. A covenant by the purchaser to reassign $50 \%$ of the interests purchased to the vendor "upon recovery by it from production ... of its costs of the acquisition of the Assignor's interest ... and all subsequent drilling, completion and operating costs ... together with interest on the declining balance on such costs (costs being actual costs from time to time incurred, less revenue as it is received) to be compounded semiannually..."

In 1970, the purchaser sent authorizations for expenditures ("AFE's") and well programmes with respect to three proposed wells to the working interest partners. None of the working interest partners in the first two proposed wells consented to the drilling thereof. One of the two working interest partners in the third well did consent but the other did not. Under the terms of the operating agreements applicable to the undrilled lands, the purchaser did not require the consent of the other working interest partners to drill the wells but if the working interest partners did not wish to

61. Unreported, 22 April 1986, No. $8001-10497$ (Alta. Q.B.). 
participate in the drilling, the purchaser would be required to pay the costs attributable to the interests of the non-participating partners. Presumably, the operating agreements provided that, in that case, the purchaser would have been entitled to recover such costs out of revenues attributable to the non-participating partners' interests. The purchaser subsequently forwarded AFE's proposing the drilling of wells on 11 of the remaining 12 spacing units comprised in the purchased lands. No well programmes were included with such AFE's. In the case of each of these proposed wells, at least one partner did not consent to the drilling of the well. The 15th spacing unit was owned $100 \%$ by the purchaser.

The Court found that the word "consent" used in the drilling covenant meant the consent of the working interest partners to the drilling and completing of the wells and the proportionate sharing of the costs thereof in accordance with their working interests. Since all of the partners did not agree to pay their proportionate share of the costs, the consents referred to in the drilling covenant were not obtained and the purchaser was relieved from its obligations thereunder.

The Court rejected the vendor's argument that the first three AFE's were insufficient because they did not indicate a commencement date for the proposed wells and that the subsequent 11 AFE's were defective because they did not contain commencement dates or well programmes. The Court stated that it is likely that an AFE should contain the proposed commencement date, location and depth of the proposed well and the estimated cost of drilling and completing same. However, the drilling covenant contained in the sale agreement did not require that an AFE be submitted to the working interest partners. The Court found that the purchaser had made a bona fide request for consent, within the meaning of the drilling covenant, from the working interest partners, that such consent had not been obtained and that the purchaser was not in breach of the covenant. It is unclear why the Court did not find that the defendant was not required to drill on the spacing unit in which it had a $100 \%$ interest.

The issue which arose with respect to the second covenant was whether or not the interest referred to therein accrued on the purchase price as well as the costs of drilling and completing wells. The Court found that interest accrued on the purchase price. The defendant submitted that the Court. should resolve the issue on the basis of an interim letter agreement which preceded the conveyance. The plaintiff submitted that the provisions of the letter agreement were merged in the conveyance agreement. The Court held that it could only refer to the earlier agreement if there was an ambiguity in the conveyance. It found that there was no ambiguity.

The Court also rejected an argument by the vendor that the provisions for interest were unenforceable by virtue of section 4 of the Canada Interest Act, ${ }^{62}$ which provides, in part, as follows:

Whenever any interest is, by the terms of any written or printed contract, . . . made payable ... . at any rate or percentage for any period less than a year, no interest exceeding the rate or percentage of five percent per annum shall be chargeable . . . unless the contract contains an express statement of the yearly rate or percentage of interest to which such other rate or percentage is equivalent.

62. R.S.C. 1970 , c. I-18. 
The covenant for reassignment provided for interest "to be compounded semi-annually, calculated at the lowest prime bank rate of interest in effect from time to time during the currency hereof, plus one percent (1\%)". The Court rejected the vendor's argument, on the basis that section 4 of the Interest Act applied only to repayments of loans and that, in any event, the contract did not specify any period for the calculation of interest, much less a period of less than one year.

The vendor also contended that the defendant had waived its right to claim interest because it had periodically provided the purchasers with accounting statements which did not include interest. The Court stated that waiver can only occur if a party has intentionally relinquished a known existing legal right which was not the situation in this case. In any event, the vendor did not act on the inaccurate statements nor was it prejudiced by them. The Court found that there had been no waiver.

It is interesting that the Court refused to admit expert testimony as to the meaning of the word "consent" when construing the drilling covenant on the grounds that the word was not ambiguous.

\section{BRYANv. KEMP AND FIZELL ${ }^{63}$}

Kemp was the owner of certain farm lands. The lands were leased to Fizell. The lease contained a right of first refusal clause. The owner agreed to sell the lands to Bryan pursuant to a sale agreement dated January 26, which was expressly subject to mortgage approval being obtained before February 8 and "subject to first right of refusal by tenant on or before February 3, 1984". The lease did not specify the time within which the tenant was entitled to exercise the right of first refusal. Notice was given to the tenant who exercised the right of first refusal on February 10. Thereafter, the original purchaser filed a caveat claiming an interest in the lands based upon its agreement of purchase and sale. Some time later the caveat was discharged and title registered in the name of the tenant. In this action, the original purchaser sought damages from the owner for failure to complete the sale and the owner counter-claimed for damages which he suffered because the sale to the tenant was delayed by the registration of the original purchaser's caveat.

The Court found that the February 3 date for exercise of the first refusal was recognized by the owner and the original purchaser as being an unrealistic date by which the tenant could decide if it wished to exercise the right of first refusal. Further, the owner did not have mortgage approval by February 8.

It was clear that the original purchaser knew of the right of first refusal. The Court found that the original purchaser consented to an extension of time in which the tenant could consider its right of first refusal. It is not clear on what basis the Court made that finding.

The Court ruled that the original purchaser was not entitled to recover damages from the owner and that the owner was entitled to recover damages from the original purchaser resulting from the registration of its caveat. Such damages were computed to be interest at $12 \%$ per annum on

63. (1985) 42 Sask. R. 191 (Q.B.). 
the purchase price payable by the tenant for the period between the time when the purchase price would have been paid if the caveat had not been registered and the time that the caveat was discharged.

\section{FREEHOLD LEASES}

\section{A. PACIFIC CASSIAR LTD. v. ESSO CANADA RESOURCES LTD..$^{\circ 4}$}

This is an appeal of a decision which was described in the 1985 edition of this paper. ${ }^{65}$ Imperial Oil had acquired a freehold lease covering all of Section 8 in 1952. It registered caveats in respect of that lease at the appropriate Land Titles Office in respect of the whole of Section 8. In 1960 , the east half of Section 8 was unitized. The lessor executed the unit agreement. The lease did not contain any provisions relating to unitization. A caveat in respect of the unit agreement was registered against the east half of Section 8, but not the west half.

In 1978, Western Land Services acquired a petroleum and natural gas lease of the west half of Section 8 which was assigned to the plaintiff.

There was continuous production from the unit at all material times.

There were two issues considered by the Court of Appeal. First, did the unitization continue the original lease as to the whole of Section 8 or only as to the unitized portions thereof? Secondly, did the failure to file a caveat in respect of the unitization agreement against the west half of Section 8 prior to the plaintiff having registered a caveat in respect of the 1978 lease result in the 1978 lease having priority?

The unitization agreement to which the lessor was a party provided that production of petroleum substances from any part of the unitized zone shall ". . . be considered as . . . production from each tract and . . . shall operate to continue in force and effect each lease . . . as if . . . a well had been drilled on and was producing from the unitized zone underlying each such tract". The unitization agreement also provided that: "the terms and provisions of the various leases .... are hereby amended to the extent necessary to make them conform to the terms ... of this Agreement". The original lease was for a term of 10 years and "so long thereafter as the leased substances or any of them are being produced from the said lands". The Court found that by virtue of the unitization agreement, production from the unitized lands was production from the said lands for purposes of the habendum clause of the original lease. As a result, the original lease continued to be in full force and effect as to all of the lands covered thereby, including the non-unitized lands. The Court found that when the appellant filed its caveat in respect of the 1978 lease covering the nonunitized lands, there was no caveat filed in respect of the unit agreement against those lands. In a dispute between the appellant and the respondent as to the priorities of their respective interests, the appellant could only claim the interest claimed in its original caveat, being the interest granted by the lease prior to its amendment pursuant to the unitization agreement. Accordingly, the 1978 lease had priority over the original lease. 


\section{PUBLIC UTILITIES}

\section{A. HUSKY OIL OPERATIONS LTD. v. SARATOGA PROCESSING COMPANY LIMITED $*$}

Saratoga operates a gas processing plant. The plant was originally designed to process raw gas produced from the Savana Creek Field on behalf of Husky and its partners. The plant was not being fully utilized and Coseka and its partners were granted the right to have gas produced from the North Coleman Field processed in the plant. A dispute arose as to the allocation of the cost of fuel used in the plant between the Savana Creek producers and the North Coleman producers. A determination on that issue was made by the Alberta Petroleum Marketing Commission. It was appealed to the Public Utilities Board of Alberta whose decision was appealed in the present case.

Husky contended that costs of fuel gas should be allocated between the two producer groups on the basis of the ratios of the volumes of gas which each delivered to the plant for processing. The Court rejected that contention because the evidence established that fuel consumption increased when the percentage of Savana Creek gas being processed increased. Thus, the processing of the Savana Creek gas required more fuel than the processing of the North Coleman gas. However, there did not appear to be a direct relationship. The greater the quantity of North Coleman gas, the greater the savings achieved by both producer groups. The Public Utilities Board apportioned the cost of fuel on the basis of historical evidence as to the volumes of gas delivered by each producer group. The Court found that it was open to the Board to adopt such a method. However, it ordered adjustments be made, periodically, if the actual streams departed in quality and composition from the average streams upon which the Board's finding was based.

\section{CREDITOR-DEBTOR RELATIONS}

\section{A. KIMWOOD ENTERPRISES LTD. v. ROYNAT INC. ${ }^{\circ}$}

Predecessors of Kimwood had sold shares of six companies. The sale agreement provided that the purchase price would be reduced if there was a reassessment of income taxes. Following the sale, the six companies and the purchaser were amalgamated. The amalgamated company granted a debenture to Roynat and a general assignment of book debts to Canadian Imperial Bank of Commerce. Thereafter, Revenue Canada reassessed the taxes of the six companies and, as a result, $\$ 100,000$ out of the purchase price, which had been retained in trust by solicitors, was paid to Revenue Canada in respect of the reassessment. The vendors had assigned all of their interest in the sale agreement to Kimwood. Kimwood challenged the reassessment which resulted in the reassessment being reduced by $\$ 30,000$. Cheques in that amount were issued by Revenue Canada in favour of the companies whose taxes had been reassessed and delivered to the amalgamated company, who was insolvent.

66. Unreported, 11 December 1985, No. 15360 (Alta. C.A.).

67. (1985) 15 D.L.R. (4th) 751 (Man. C.A.). 
The issue in the case was the priority of Kimwood's entitlement to the refund cheques under the purchase agreement versus the defendant's entitlement to the cheques under the security interests granted to it by the amalgamated company.

The Court held that the law implied a trust in favour of Kimwood in the circumstances, so that the amalgamated company or its secured creditors hold the proceeds of the cheques as trustee for the plaintiff. The Court held that a trust would be constructed in these circumstances to prevent unjust enrichment. The Court held that the contest in the case was not between creditors holding security interests. The Court noted that when the defendants made their loans and took security, that security did not include the cheques. This was not a situation in which the loans were based on the security of certain property with no notice that such property was affected by a trust. It is not clear from the decision whether the proceeds from the rebate of the reassessment were commingled with the amalgamated company's other funds but it would appear that they were not.

It is submitted that when an operator receives revenues on behalf of nonoperating working interest owners, the operator may receive such revenues as a trustee. In a contest between the operator's creditors and the other working interest owners or royalty owners entitled to a share of the production revenues, the Kimwood case could be quoted as authority for the proposition that the operator and its creditors received the nonoperator's working interest shares of such revenues and, perhaps, royalty owners' shares of such revenues subject to a constructive trust in their favour. The case might possibly be distinguished if the operator is entitled to and does commingle the revenues with other funds.

\section{B. ARMSTRONG v. COOPERS \& LYBRAND LIMITED}

The Royal Bank of Canada had taken security pursuant to section 178 of the Banks and Banking Law Revision Act ${ }^{69}$ from Canadian Admiral Corporation Limited. Admiral defaulted on its loans and the bank appointed a receiver. Former employees of Admiral sought to recover vacation pay pursuant to section 15 of the Employment Standards Act, ${ }^{70}$ which provides that vacation pay "becomes a lien and charge upon the assets of the employer". The pertinent issue was the priority of the statutory lien for vacation pay over the security interest granted to the bank. The Court held that when a bank takes security under section 178 of the Bank Act," the Bank cannot receive any greater right than the assignor itself possessed. If the assets in question were subject to the statutory lien for vacation pay at the time that the section 178 security was granted, then the bank's security was subject to the lien for vacation pay. The section 178 security agreement provided for the granting of security on future acquired property. The Court found that when such property was acquired by Admiral, a security interest therein was automatically assigned to the

\footnotetext{
68. Unreported (Ont. C.A.).

69. S.C. $1980-81-82-83$, c. 40.

70. R.S.O. 1980, c. 137.

71. Supre n. 69.
} 
bank. However, prior to that automatic assignment, the property became subject to the statutory lien. Accordingly, the statutory lien had priority over the bank's security.

Section 177 of the Bank Act, ${ }^{n}$ which governs security interests in hydrocarbons granted to a bank, contains language similar to that in section 178 of the Bank Act, to the effect that security thereunder covers property of which the assignor is the owner or becomes the owner. The Armstrong case may be applicable to section 177 security interests.

The Court reviewed the nature of section 178 security and stated that during the course of a loan secured by a section 178 assignment and prior to a default, the borrower has the right to sell the goods covered by the bank's security in the ordinary course of business and to give good title thereto to its purchasers. The Court stated that it did not consider security given under section 178 as being in the nature of a fixed or specific charge, but rather in the nature of a floating charge. Those statements are clearly obiter dicta. However, if they are correct, they may be applicable to section 177 security which functions in a way similar to section 178 security.

\section{SURFACE RIGHTS}

\section{A. FLETCHER v. NORCEN ENERGY RESOURCES LIMITED ग}

Surface leases for the well sites of four oil wells were granted by a cattle farmer in 1953. The leases were for renewable terms of 25 years.

The lessor sought to recover: (i) damages to her property resulting from the defendant's operations on the well sites, (ii) damages for trespass by the defendant, and (iii) damages resulting from breach of a covenant by the defendant to provide natural gas to the lessor.

The Court awarded the lessor damages resulting from the defendant's operations as follows: the value of the plaintiff's cattle which the plaintiff sold because the cattle's health deteriorated as a result of ingesting crude oil from two spills from the defendant's wells and fiberglass insulation which blew off the defendant's well sites; damage to the plaintiff's car resulting from a collision with a protruding pipe installed by the defendant and located off the well sites; and damages resulting from the defendant's trucks having crossed the plaintiff's farmland to get to and from the well sites.

Although there was no direct evidence that the damages had resulted from the defendant's operation, it was a reasonable inference in the circumstances having regard to the nature of the damages suffered and the evidence as to the defendant's normal method of conducting operations.

The Court awarded the plaintiff damages for trespass to the well sites. Although there is no discussion in the Court's written judgment, it is assumed that the renewal covenant in the leases was not applicable because the lessee was in default. The Court rejected the defendant's argument that since negotiations for a new lease had been ongoing, the plaintiff had impliedly authorized the continuation of operations on the well sites. The plaintiff had continuously complained of the defendant's operations to the

72. Id.

73. (1985) 67 A.R. 21 (Alta. Q.B.). 
field operator which negated any suggestion of implied consent to occupation of the well sites after expiry of the leases. Although the field operator was an independent contractor and not an employee of the defendant, the defendant had impliedly appointed the field operator as its agent for purposes of the leases, so that complaints to the field operator constituted complaints to the defendant.

The Court ordered exemplary damages for the trespass, as it found the defendant's actions reprehensible because it deliberately disregarded the rights of the plaintiff in continuing its operations until physically barred from the well sites.

The Court also awarded the plaintiff compensation for the defendant's failure to supply gas during the period commencing six years prior to the commencement of the action, presumably as a consequence of the Limitations Act, and ending upon expiry of the initial term of the leases, excluding a period in which no gas was produced from the wells.

\section{B. GABERT v. ARIES RESOURCES LIMITED AND TRIWELL OIL FIELD CONSTRUCTION LTD. ${ }^{74}$}

This is an action by the plaintiff surface owner pursuant to the terms of certain pipeline easements, to recover damages from Aries Resources Limited resulting from the installation of a pipeline along such easements. Aries sought indemnification from Triwell Oil Field Construction Ltd., whom it had contracted to install the pipeline on its behalf. The easements contained a clause which stated:

Off right-of-way travel will be paid to the Grantor at the rate of $\$ 500$ per occurrence. The Grantor and the Grantee will assess the right-of-way travel at the end of the construction together, and payment will be made no later than five (5) working days later. This is a demand trespass clause.

That provision was inserted in the easement because of the plaintiff's concern that the width of the easement was insufficient to allow the construction of the pipeline to be carried out entirely within the right-ofway. Aries had refused the plaintiff's request that the easement be wider. The Court found that the deemed trespass clause was intended to protect the plaintiff from any significant activity carried on by vehicles and equipment off the right-of-way but was not intended to cover trivial trespasses such as "windrows" of soil pushed off the right-of-way accidentally or by rainfall. The clause was designed to cover separate, identifiable instances of equipment at work off the right-of-way. The Court found that there were 17 such occurrences, each of which entitled the plaintiff to $\$ 500$.

The Court found that Triwell was required to indemnify Aries for the judgment by virtue of a provision in the construction contract which stated as follows:

All off right-of-way damages regardless of the reason and extra costs for working space are to the account of Triwell.

Triwell was aware, at all times, of the possibility that the right-of-way might not be sufficiently wide.

74. Unreported, 31 December 1985, No. 8210-10480 (Alta. Q.B.). 


\section{CABRE EXPLORATION LTD. v. ARNDT"s}

This was an appeal of the compensation awarded to the surface owner in respect of a right of entry order issued by the Alberta Surface Rights Board pursuant to the Surface Rights Act. ${ }^{76}$ That Act establishes a Surface Rights Board which can grant a right of entry order for purposes of exploiting minerals when the owner of the surface and the owner of the minerals are unable to agree to the terms whereby the mineral owner will use the surface owner's lands to exploit the minerals. Section 25 of the Act sets forth the factors which may be considered by the Surface Rights Board in computing compensation to be paid to a surface owner in respect of a right of entry order. Section 26 of the Act provides that an appeal of a compensation order may be made to the Court of Queen's Bench. An appeal is to be in the form of a new hearing.

In this case, the mineral owner contended that the Surface Rights Board only had authority to compensate the surface owner for its loss. The mineral owner further argued that since, at common law, the mineral owner had the right to use the surface without payment of compensation, the surface owner.suffered no loss as a result of the issuance of the right of entry order. The Court rejected that argument, even though it seemed logical, because it flew in the face of the clear intention of the Act. The Court stated that the Act required that the mineral owner pay the surface owner as if surface rights were taken from the surface owner.

The mineral owner also appealed the quantum of the compensation awarded by the Surface Rights Board. The Court stated that section 25 of the Act does not set out an exclusive list of the headings under which compensation is to be awarded, nor is it necessary for the Board to award compensation under each of the headings set forth therein. However, the Board must consider all of the factors listed therein and may not ignore them. The factors set out in section 25(1)(a) and (c) of the Act are, respectively, the fair market value of the land covered by the right of entry order and the loss of use by the surface owner of that land. The Court found that in computing the compensation to be awarded in respect of the fair market value of the land, an adjustment for the residual value of the land which will revert to the surface owner when the mineral owner's operations are completed, must be taken into account. The Court also found that damages under both section 25(1)(a) and (c) should not be awarded, since compensation for the fair market value of the land already takes into account the loss of use of the land.

Section 25(1)(e) of the Act.allows the Board to award compensation for damages "that might be caused by the operations of the operator". The Court was troubled by the use of the word "might" in that section, but preferred the view that it authorized the Board to compensate the surface owner for damage which the operator may cause in the future. The Court stated that the Board ought to exercise considerable discretion in making awards under section 25(1)(e), since the Board's function is to compensate for loss and it is preferable to make no award or only a nominal award until

75. (1986) 69 A.R. 293.

76. S.A. 1983 (Spring), c. S-27.1. 
loss is actually suffered. Periodic reviews of compensation orders are permitted under the Act.

Section 25(1)(f) of the Act permits compensation for nuisance and disturbance. Although the Court found the evidence in this case on that heading to be controversial, it found that it should not disturb the award of the Board, because the Court is required to accord substantial evidentiary value to the Board's decisions.

\section{LECUYER CATTLE CO. LTD. v. COOPERATIVE ENERGY DEVELOPMENT CORPORATION"}

This was an appeal by a non-owner occupier under the Alberta Surface Rights Act, ${ }^{n}$ of the Surface Rights Board's refusal to take into account, under paragraph $25(1)(f)$, the amount negotiated by him with other operators in the area for consents to entry. The Court held that this was not a relevant factor to be considered under either paragraph $25(1)(a)$ or (b), as it was not evidence of a sale nor of the per acre value of a title unit. Furthermore, it was not a proper factor falling within the "basket" provisions of paragraph $25(1)(f)$, since it is not compensatory in nature. The Court held that it does not shed any light upon the quantum of the occupant's loss, and dismissed the appeal.

\section{E. DOME PETROLEUM LIMITED v. RICHARDS AND ALBERTA POWER LTD. (and eleven other actions)"}

These twelve cases deal with appeals from decisions of the Alberta Surface Rights Board in respect of lands in the Grand Prairie area. The Board was taking two very different approaches in fixing compensation, which resulted in very different amounts of compensation. The first of these approaches required that every site be considered strictly on the basis of its own unique situation. The second approach required that all relevant factors be taken into consideration in a "global approach" to compensàtion. The Court held that an area agreement negotiated by several surface rights groups in the Grand Prairie and Peace River areas with several oil companies should be given great weight by the Court, since they represented the best evidence available to determine the value of the taking to both sides. Utilizing a formula approach or a global flat rate would not offend the Surface Rights Act. ${ }^{80}$ However, where there are no area agreements, the guidelines in section 25 of the statute should be applied, without restriction, to the "four heads" enumerated therein. The purpose of the statute is to encourage land owners and operators to resolve their differences. Secondarily, it is to provide machinery for an expeditious method of fixing compensation when the parties cannot reach agreement.

77. [1985] 5 W.W.R. 555 (Alta. Q.B.).

78. Supra n. 76.

79. (1985) 42 Alta. L.R. (2d) 97, 66 A.R. 245.

80. Supren. 76. 


\section{F. WALDE v. GREAT BASINS PETROLEUM LTD."}

This was an appeal of a judgment of the Alberta Court of Queen's Bench of an award of compensation, following an appeal from the award of compenstion granted by the Surface Rights Board pursuant to the Surface Rights Act. ${ }^{22}$

The surface owner contended that the Board and the Trial Court erred in refusing to consider the compensation paid by oil companies to the Eastern Irrigation District, a major land owner in the area, under a large number of negotiated surface leases. The Court of Appeal stated that comparable leases freely negotiated at arm's length should be considered, since they are the best test of the value of the land. The Board had rejected the comparable leases on the grounds that it had no evidence whether the adverse effect on other lands covered by such other leases was comparable to the adverse effect on lands covered by the Right of Entry Order. The Court of Appeal would have accepted that ruling except that the Trial Judge had refused to hear evidence in that regard. Since the appeal of the award of the Surface Rights Board to the Court of Queen's Bench is to be by way of a new hearing, the Trial Judge ought to have accepted such evidence. As a result, the Court of Appeal ordered that a new hearing be held.

\section{G. LOMOND GRAZING ASSOCIATIONv. PANCANADIAN PETROLEUM ${ }^{\text {83 }}$}

This was an appeal of the award of compensation made by the Alberta Surface Rights Board pursuant to the Surface Rights Act ${ }^{24}$ in respect of a Right of Entry Order. The only evidence before the Board was of compensation paid under comparable surface leases. The Court stated that the established theory that compensation awards made by the Board should be disturbed only if there is cogent evidence for doing so, may no longer be appropriate because that theory was established at a time when the Board's case load was much lighter than it is now and when proceedings before the Board were informal and involved less complex issues, such as taxation, economics and real estate, than is currently the case. In any event, a decision of the Board which is unsupported by evidence is reviewable. In the present case, the only evidence before the Board was that of the comparable leases, so that the Board's decision was unsupported by evidence. The Court stated that comparable leases should only be relied upon when they are freely negotiated. In many cases, surface leases are not freely negotiated because of the threat of the compulsory provisions of the Surface Rights Act."s

The surface owner had tendered as evidence a large number of leases comparable geographically, agriculturally and time-wise to the instant situation, all of which were with a single surface owner. The mineral owner

81. (1985) 65 A.R. 358 (Alta. C.A.).

82. Supra $\mathrm{n} .76$.

83. (1985) 63 A.R. 120 (Q.B.).

84. Supran. 76.

85. Id. 
had submitted a large number of comparable leases covering a larger geographical area than those submitted by the surface owner, which were with only two mineral owners. The Court found that the comparables submitted by the surface owner were more likely to be freely and voluntarily entered into without compulsion, because the mineral owners and the surface owner involved in those leases were knowledgeable and sophisticated. As a result, the Court varied the award of the Board based upon the comparables submitted as evidence by the surface owner.

\section{H. TRANSALTA UTILITIES CORPORATIONv. MALMBERG ${ }^{86}$}

In 1981, the Alberta Surface Rights Board made a compensation award in respect of a Right of Entry Order granted to TransAlta for the purpose of constructing and operating an electrical transmission line. In 1985, the surface owner requested the Board to review the annual compensation payable under that award pursuant to section 27 of the Surface Rights Act." The Board confirmed the original award. This is an appeal of the review.

The Court stated that since such appeals are in the nature of a new hearing, the Court ought not to refer to the evidence given to the Board but should be limited to the evidence before the Court. In its original award, the Board did not indicate how it arrived at the annual compensation it awarded, so that the Court ought to make its own findings. The Court stated that because of the complexity of the situation, settlements made with other land owners in comparable circumstances can be taken into consideration. The Court reduced the Board's annual compensation award to that equivalent to the compensation paid to other landowners in comparable circumstances.

\section{CABRE EXPLORATION LTD. v. ARNDT AND SURFACE RIGHTS $B O A R D$ *}

The mineral owner objected to the costs awarded to the surface owner by the Surface Rights Board in an application under the Surface Rights Act. 89 The mineral owner argued that the Board has a policy of awarding costs to the surface owner, never considers the mineral owner as a person entitled to costs, and never gives the mineral owner an opportunity to oppose the costs awarded to the surface owner. The Court found that there was no evidence to suggest that there was any such policy or that the Board exercises its discretion in granting costs in any improper way. Neither party was invited in this case to apply for costs although the surface owner requested same. Since the Board's award exceeded that which had been offered by the mineral owner, the mineral owner should not have been surprised that the surface owner was awarded costs. The mineral owner's appeal was dismissed.

86. (1985) 67 A.R. 306 (Alta. Q.B.).

87. Supra n. 76.

88. Unreported, 8 April 1986, J.D. of Edmonton, No. 8503-31802 (Alta. Q.B.).

89. Supre n. 76. 
IVOL. XXV, NO. 1

\section{J. CABRE EXPLORATION LTD. v. ARNDT AND THE ATTORNEY GENERAL OF ALBERTA ${ }^{\circ}$}

Cabre contested the constitutional validity of section $26(9)$ of the Alberta Surface Rights Act ${ }^{\text {II }}$ which provides, in part, as follows:

26(9) The costs of an appeal under this section,

(a) when the appeal is by the operator, are payable by him on a solicitor and client basis . ..

(b) when the appeal is by the owner or occupant,

(i) if the appeal is successful, are payable by the operator on a solicitor and client basis, and

(ii) if the appeal is unsuccessful, are payable on a party and party basis to the party, if any, that the court in its discretion may direct.

The constitutionality of that provision was contested on the grounds of the Charter of Rights on the basis that the operator (the mineral owner) is treated differently thereunder than the surface owner. The Court found that the provision was not unconstitutional as it did not discriminate against the operator in a manner contrary to section 15 of the Charter of Rights.

\section{K. HARDING v. ALBERTA SURFACE RIGHTS BOARD"2}

Section 42(3) of the Alberta Surface Rights Act"s states: "The Board may order by whom the costs are to be taxed and allowed". The Court ruled that any such taxation must be referred to someone under the jurisdiction of the Surface Rights Board, so that the Board has control over the taxation; otherwise administrative and legal difficulties could ensue.

\section{GROENEVELD v. TRANSALTA UTILITIES CORPORATION*}

Section 26(3) of the Alberta Surface Rights Acts provides that a party appealing a decision of the Surface Rights Board must file a notice of appeal with the Court and must serve a copy thereof on the other parties to the order. The Court held that the copy of the notice of appeal served on the other parties to the order need not be a filed copy.

\section{GRIFFITH v. OMEGA HYDROCARBONS LTD. AND SURFACE RIGHTS BOARD \%}

In this case, it was held that the Manitoba Surface Rights Board established pursuant to the Surface Rights Act, ${ }^{n}$ does not have the jurisdiction to determine the location of a well site or to make an order as to the method of drilling.

90. Unreported, 8 April 1986, J.D. of Edmonton, No. 8503-19134 (Alta. Q.B.).

91. Supra n. 76.

92. (1985) 32 L.C.R. 381 (Alta. Q.B.).

93. Supra $\mathrm{n} .76$.

94. (1985) 66 A.R. 159 (Alta. Q.B.).

95. Supra n. 76.

96. [1986] 2 W.W.R. 622 (Man. Q.B.).

97. S.M. 1982-83-84, c. 4. 


\section{CONSTITUTIONAL LAW}

\section{A. OMINAYAK v. NORCEN ENERGY RESOURCES LTD.}

The Lubicon Indian Band brought a class action claiming aboriginal title to certain traditional hunting and trapping grounds in North Central Alberta. The defendants, the Province of Alberta and oil companies engaged in exploration and development of the lands, disputed the claim. The Band sought an injunction to prevent further exploration and development and an order for possession of the lands. The Band was not successful at trial and appealed. The Appellate Court stated three requirements that must be met for an interim injunction to be granted: (1) there must be a serious issue to be tried; (2) there must be irreparable harm if the injunction is not granted; and (3) the balance of convenience between the parties must favour the injunction. The Court found that there was a serious issue of aboriginal title and that the Band would not suffer irreparable damage if the oil and gas exploration and development continued as it did not unduly interfere with their hunting and trapping activities. On the other hand, the Court held that the injunction would have severe economic impact on the oil and gas companies and the balance of convenience favoured the denial of the injunction.

\section{B. MACMILLAN BLOEDEL LIMITED v. MULLIN; MARTINv. R. IN RIGHT OF BRITISH COLUMBIA ${ }^{\circ}$}

This case dealt with the application by MacMillan Bloedel Limited for an interim injunction to prevent interference with its logging operations on Mears Island. The injunction was obtained at trial but two Indian bands appealed, claiming a declaration of aboriginal rights to the island and seeking an injunction preventing logging until the action was tried. The majority of the Court was of the opinion that there was a serious issue to be tried as to aboriginal title and the Indians would suffer irreparable damages if the island was logged. However, the Court stated that MacMillan Bloedel Limited would not suffer irreparable harm as it had other sites to $\log$. The Court held that justice and convenience favoured the band and an injunction preventing logging operations until trial was granted.

\section{ADMINISTRATIVE LAW}

\section{A. RE ONTARIO ENERGY BOARD 100}

A stated case was brought before the Court respecting the power of the Ontario Energy Board (the "OEB") to award interim costs to intervenors in order to fund their participation in a hearing. The Court was of the opinion that the powers given to the OEB to award costs pursuant to section 31 of the Ontario Energy Board Act ${ }^{101}$ did not grant the jurisdiction

98. (1985) 36 Alta. L.R. (2d) 137 (Alta. C.A.).

99. (1985) 61 B.C.L.R. 145 (B.C.C.A.).

100. (1985) 19 D.L.R. (4th) 753 (Ont. H.C.J.).

101. R.S.O. 1980, c. 332. 
[VOL. XXV, NO. 1

to fund, in advance, intervener participation. The Court held that costs were awarded and payable at the conclusion of the proceeding for allowable expenses and services incurred in the proceeding and that they are not payable for the purpose of assuring participation in the proceeding.

\section{B. ENERGY RESOURCES CONSERVATION BOARD DECISIONS}

\section{Decision D85-31: Westcoast Petroleum Ltd. Gas Processing Plant Pipeline Permit Application}

This decision deals with an application by Westcoast Petroleum Ltd. ("Westcoast") to construct a new gas plant and gas sales pipeline to process solution gas from the Crystal Viking A Pool. Bumper Development Corporation Ltd. ("Bumper") objected on the basis that it had an existing plant and pipeline with excess capacity; it was willing to process Westcoast's gas; it had offered Westcoast an equity position in the plant; and it was willing to expand the facilities if necessary. Westcoast wanted to be the operator of its own plant and took the position that, as it was the largest interest holder in the field, it had the right to construct and operate its own facilities. The Energy Resources Conservation Board ("ERCB") found that both plants provided for conservation of solution gas and that the environmental impact of the second plant was minimal. As the ERCB was satisfied with the conservation and environmental aspects of Westcoast's application, it saw no reason to intervene in normal business transactions. Accordingly, Westcoast's plant and pipeline were approved by the ERCB.

\section{Decision D 85-33: Anderson Exploration Ltd. Approval To Modify} Existing Dunvegan Gas Plant To Recover Ethane-Plus Liquid

Anderson Exploration Ltd. ("Anderson") applied for approval to construct deep-cut facilities at its existing Dunvegan gas processing plant. Anderson's application was opposed by a number of straddle plant owners and petrochemical producers on the basis that extraction of ethane at field plants would reduce the amount of ethane available to the straddle plant and petrochemical producers as feed stock and increase their costs of extracting ethane. The ERCB denied Anderson's application, on the basis that even though Anderson's facilities would produce incremental ethane at competitive costs and a market had been secured, these field facilities would have a negative impact on the straddle plants and the petrochemical producers as Anderson's ethane would merely displace existing ethane markets and there would be a loss of efficiency in the straddle plants due to a leaning of the inlet gas.

\section{NATIONAL ENERGY BOARD DECISIONS}

During the past year, the National Energy Board ("NEB") held hearings and issued a number of decisions in connection with the partial decontrol of natural gas marketing and pricing during the transaction period November 1, 1985 until November 1, 1986. The matters dealt with by the NEB included approvals for gas exports and pricing, TransCanada Pipelines Limited's rates and tolls and the restructuring of the export reserve test. These matters are not dealt with in this paper, as they were 
discussed in the separate papers on natural gas deregulation presented at the 1986 Canadian Petroleum Law Foundation Annual Research Seminar.

\section{GOVERNMENT AGREEMENTS}

\section{A. NATURAL GAS PRICING AGREEMENT OCTOBER 31, 1985, A.R. 134/85, 365/85}

The Governments of Alberta, British Columbia and Saskatchewan reached agreement with the federal Government on October 31, 1985 with respect to natural gas pricing and marketing. The Natural Gas Agreement provides for a transition to market pricing for natural gas commencing November 1,1985 , to be fully implemented by November 1,1986 . On November 1, 1986 the price of all natural gas will be determined by negotiations between buyers and sellers. During the twelve-month transition period, there will be partial deregulation. The Alberta border price will be frozen at \$2.90 per MCF until November 1, 1986 and the governments will continue to prescribe the price for natural gas. However, for domestic sales, prices may be negotiated for new system sales, contracts which have expired, competitive market programs and direct sales in respect of which carriage is available.

The federal Government committed to the following measures to provide for more open access by Canadian producers to the export markets: the Toronto wholesale floor price is to be replaced by the adjacent border pricing test, the surplus test will be reviewed and the regulations will be amended to allow the export of natural gas by order of the NEB without volume limitation for terms not exceeding 24 months. The federal Government also undertook to ensure that direct sales have equitable and open access to TransCanada Pipelines Limited's transmission facilities. The Alberta Government agreed to amend the Arbitration Act, R.S.A. 1980 , c. A-3 and the removal permit process, to ensure that these are consistent with the Agreement. The Agreement calls for the NEB to be asked to review the pertinent issues regarding pipeline access and tolls. The governments also agreed to initiate a comprehensive review of the role and the operation of pipelines engaged in buying, selling and transporting natural gas.

\section{ALBERTA LEGISLATION}

\section{A. ALBERTA STATUTES}

The fourth session of the 20th Legislature convened on April 3, 1986. There was no fall sitting of the Legislature in 1985. The following Bills were introduced prior to the dissolution of the Legislature on April 9, 1986.

\section{Natural Gas Pricing Agreement Amendment Act, 1986, Bill 1}

This Bill implements aspects of the Natural Gas Agreement dealing with the partial decontrol of natural gas pricing during the transition period from November 1, 1985 to November 1, 1986. Provision is made to prescribe the regulated field price for different classes of natural gas sales and the price adjustment mechanism is amended to reflect these prices. The Natural Gas Pricing Agreement Amendment Regulations, Alta. Reg. $384 / 85,105 / 86$ are ratified. 
[VOL. XXV, NO. 1

\section{Alberta Stock Savings Plan Act, Bill 2}

This Bill establishes a tax credit to reduce Alberta Income Tax where an investor purchases eligible shares from an eligible corporation and deposits the shares in a stock savings plan. To be eligible, a corporation must be incorporated in Canada, listed on the Alberta Stock Exchange, pay $25 \%$ of its wage and salary cost to employees in Alberta, the value of its assets must not exceed $\$ 500$ million and, unless it is an Alberta-based financial institution, not more than $50 \%$ of its assets may be composed of financial instruments. There are three classes of eligible corporations: an emerging corporation having assets from zero to $\$ 5$ million and net revenues from zero to \$6 million; an expanding corporation having assets from \$5 million to $\$ 50$ million and net revenue from \$6 million to \$20 million; and mature corportions being all other corporations having assets less than $\$ 500$ million. Eligible shares must be listed on the Alberta Stock Exchange and either be non-redeemable, non-retractable common shares with full voting rights or non-redeemable preferred shares of an emerging corporation which are convertible into eligible common shares. A share will not be eligible if it is a flow-through share or if the investor has claimed the scientific research tax credit, the share purchase tax credit or the small business equity corporations incentive. The stock savings plan is set up with registered securities dealers in Alberta who hold the shares. The maximum annual tax credit is $\$ 3,000$ and is based on the cost of the eligible shares with $30 \%$ for emerging corporations, $15 \%$ for expanding corporations and $10 \%$ for mature corporations. The tax credit will be recaptured if the investor does not maintain the level of investment in the stock savings plan following the purchase of the shares.

\section{Alberta Corporate Income Tax Amendment Act, 1986, Bill 14}

This Bill introduces several provisions designed to prevent multiplication of the Alberta Royalty Tax Credit. The tax credit will not be available where control of a restricted corporation is acquired, unless the Provincial Treasurer is satisfied that the result of the acquisition of control is not to increase the tax credit. In addition, the definition of "restricted resource property" has been broadened.

\section{B. ALBERTA REGULATIONS}

1. Deregulation Of Petroleum Marketing, Alta. Reg. 150/85, 151/85, $152 / 85,153 / 85,154 / 85,155 / 85,156 / 85,169 / 85,190 / 85,191 / 85$, $255 / 85,256 / 85,270 / 85,352 / 85,41 / 86,61 / 86$

The deregulation of petroleum marketing on June 1, 1985 made amendments to several of the Alberta regulations necessary. The Marketing Provision Regulation, 1981 (Alta. Reg. 443/81) was repealed. The former regulation required that both the Crown royalty and lessee's share of crude oil and pentanes plus be marketed through the Alberta Petroleum Marketing Commission (APMC). Now, only the Crown royalty portion of crude oil is required to be marketed through the APMC. The APMC has been given the power to give such directions as it considers necessary to any lessees, purchasers, pipeline operators or any other persons in conjunction 
with the marketing of the Crown's royalty share of petroleum. The Petroleum Royalty Regulations (Alta. Reg. 93/74) and Natural Gas Royalty Regulations (Alta. Reg. 16/74) were amended to reflect the elimination of the regulated price for petroleum and pentanes plus. The royalty factors and par price used in calculating the royalty for old and new oil are now prescribed on a monthly basis and have recently been amended to reflect the drop in oil prices. The royalty factors were also amended, effective August 1, 1985, to reflect the reduction in the marginal royalty rate for old oil from $45 \%$ to $43.5 \%$ and for new oil from $35 \%$ to $33.5 \%$. The Alberta Government also announced its intention to further reduce the marginal royalty rates by $1.5 \%$ on August 1,1986 and $2 \%$ on August 1 , 1987.

\section{Alberta Incentive Regulations}

During the past year the Alberta Government introduced new exploratory drilling and royalty holiday incentive programs.

(a) Geophysical and Exploratory Drilling Incentive Programs and Royalty Exemption Systems Admendments, Alta. Reg. 79/85, 80/85, 81/85, 204/85, 205/85, 206/85, 207/85, 208/85, 209/85, 210/85, $211 / 85,212 / 85,213 / 85,214 / 85$

The Geophysical and Exploratory Drilling Incentive Programs and Royalty Exemption Systems expired on August 1, 1985. Credits earned under these programs prior to July 31,1985 still exist and are available for use until December 31,1990, at which time they expire. The crude oil royalty and freehold mineral tax exemptions will expire on December 31, 1999. The natural gas royalty exemptions will continue beyond December 31, 1999.

(b) Crude Oil Royalty Holiday Program, Alta. Reg. 216/85, 355/85, 394/85, 395/85

The Oil Royalty Exemption System replaces the Exploratory Drilling Incentive System. A crude oil royalty holiday applies to all new conventional crude oil wells drilled outside existing pool boundaries on or after June 1, 1985. The royalty holiday will consist of a greater of: (1) a twelvemonth royalty free period for each eligible well to a maximum of $\$ 1$ million per well; or (2) a royalty exemption defined as a volume of crude oil for each eligible well, calculated from a depth-related schedule. The schedule takes into account variations in average drilling costs in different areas of the province. The program will be effective for a period of three years from June 1, 1985 to May 31, 1988.

(c) Exploratory Gas Well Incentive Program, Alta. Reg. 217/85, 354/85

This program also replaces the Exploratory Drilling Incentive System. A natural gas royalty holiday applies to all exploratory wells. The royalty holiday will consist of the greater of: (a) a twelve-month royalty free period for each eligible well to a maximum of $\$ 2$ million per well; or (b) a royalty exemption defined as a dollar amount to be applied against royalties payable, which exemption is to be calculated from a depth-related 
[VOL. XXV, NO. 1

schedule. In addition, a new royalty holiday program was introduced for deep gas wells. The royalty holiday applies to all new wells drilled into new gas pools or into extensions of existing pools located below 2500 meters. The royalty holiday is defined as a dollar amount to be applied against royalties payable. The dollar amount of the exemption increases with the depth drilled. The royalty formulas were also amended to reflect the reduction in the marginal rate for old gas from $45 \%$ to $43.5 \%$ and for new gas from 35\% to $33.5 \%$. The Alberta Government also announced its intention to further reduce the marginal royalty rates by $1.5 \%$ on August 1 , 1986 and $2 \%$ on August 1, 1987.

(d) Oil Royalty Exemption Amendment Regulations, Alta. Reg. 215/85

The Oil Royalty Exemption Regulation, Alta. Reg. 139/84 was extended to August 1,1985 . These regulations have been replaced by the Crude Oil Royalty Holiday Program.

3. Petroleum and Natural Gas Agreements Regulations, Alta. Reg. $188 / 85,218 / 85,253 / 85$

This regulation repealed and replaced the Petroleum and Natural Gas Lease Regulations (Alta. Reg. 168/76), the Petroleum and Natural Gas Licence Regulations (Alta. Reg. 169/75) and the Natural Gas Licence Regulations (Alta. Reg. 297/62). The regulation consolidates and amends the former regulations. The sections of the new regulation concerning petroleum and natural gas licences cover bid requirements, terms, maximum area, grouping and the selection of leases out of licences. The sections concerning the petroleum and natural gas leases deal with bid requirements, drilling requirements for ten-year leases and natural gas leases, offset drilling requirements and the procedure for approving continuation of leases. The provisions are substantially the same as the former regulations.

\section{Compensatory Royalty Regulations; Alta. Reg. 254/85, 364/85}

This regulation prescribes the prices to be used in calculating the compensatory royalty pursuant to section 22 of the Petroleum and Natural Gas Agreements Regulation (Alta. Reg. 188/85). The value of the Crown's royalty share is determined for crude oil using the new oil par price prescribed for the month, and for condensate and natural gas using the average price received in the month by the Crown for its royalty share of condensate and natural gas. Authorized costs and allowances are allowed as deductions. If the lessee provides proof satisfactory to the Minister that the average price received for the crude oil, condensate or natural gas, less authorized costs, is less than the prescribed price, then the lower price is to be used in calculating the compensatory royalty.

5. Natural Gas Pricing Agreement Amendment Regulations, Alta. Reg. 384/85, 105/86

The Natural Gas Pricing Agreement Regulations (Alta. Reg. 127/77), were amended to reflect the move towards decontrol of natural gas marketing and pricing during the transition period November 1, 1985 until 
November 1, 1986, as agreed to in the Natural Gas Agreement. The amendments revise the prescribed prices for natural gas and adopt negotiated prices for new system sales, contracts which have expired, competitive marketing programs, direct sales in respect of which carriage is available and export contracts. In addition, the price adjustment provisions were amended to account for the new prices.

\section{Designation Regulations, Alta. Reg. 171/85, 173/85}

These regulations designate the owners of gas utilities and public utilities to which the prohibitions contained in sections 25.1 and 26 of the Gas Utilities Act, R.S.A. 1980, c. G-4 and sections 91.1 and 92 of the Public Utilities Board Act, R.S.A. 1980, c. P-37 apply. As discussed in the version of this paper delivered last year, these Acts were amended such that the prohibited transactions apply only to designated utilities. The corporations which have been designated by the regulations appear to be true utilities or owners of true utilities.

\section{Natural Gas Royalty Amendment Regulations, Alta. Reg. 148/85}

The procedural provisions of the Natural Gas Royalty Regulations (Alta. Reg. 16/74) dealing with production reporting, the mechanics of the royalty payment and interest were revised.

8. The Oil and Gas Conservation Regulations Amendments, Alta. Reg. $189 / 85,265 / 85,27 / 86$

These regulations (Alta. Reg. 151/71) were amended with respect to the administration fee for wells and oil sands projects and reporting requirements for gas plants processing hydrogen sulphide. In addition, the sections requiring a drilling deposit were repealed.

9. Petroleum Incentives Program Amendment Regulation, Alta. Reg. $149 / 85$

These regulations (Alta. Reg. 220/82) were amended to allow the Minister to declare certain development expenses to be eligible exploration expenses where part of a well is abandoned within one year of drilling or where part of a well is drilled to evaluate a deeper formation. In addition, the drilling or converting costs of an observation well were added as eligible development expenses.

10. The Clean Air Regulation and The Clean Water Regulation Amendment, Alta. Reg. 24/86, 25/86

These regulations (Alta. Reg. 35/73 and 216/75) were amended to exempt certain plants processing sweet natural gas from the licencing requirements.

\section{Forms Amendment Regulations, Alta. Reg. 194/85, 195/85}

These regulations prescribe new forms to be used under the Dower Act, R.S.A. 1980, c. D-38 and the Land Titles Act, R.S.A. 1980, C. L-5. 
[VOL. XXV, NO. 1

\section{FEDERAL LEGISLATION}

\section{A. FEDERAL STATUTES}

1. An Act To Amend The Canada Shipping Act, The Arctic Waters Pollution Prevention Act, The Maritime Code Act and The Oil and Gas Production and Conservation Act, Bill C-75

These amendments revise the provisions respecting liability and compensation for pollution. The Maritime Pollution Claims Fund has been changed to the Ship-Source Oil Pollution Fund. These provisions apply in all ship-source oil pollution situations, except those where the Arctic Waters Pollution Prevention Act, R.S.C. 1970 (1st Supp.), c. 2 and the Oil and Gas Production and Conservation Act, R.S.C. 1970, c. O-4 apply.

2. An Act To Amend The Petroleum and Gas Revenue Tax and To Amend The Income Tax Act, Bill C-82

These amendments relate to the Petroleum and Gas Revenue Tax (PGRT) phase-out which was announced in the Western Accord. The amendments provide the mechanism by which production of oil and natural gas commencing after April 1, 1985 is exempted from the tax. New or incremental production, which commences after March 31, 1985 from wells drilled after that date or from deepened wells or approved recovery project, is exempt from PGRT.

3. Petroleum Incentive Program Amendments, S.C. 1986, c. 14, SOR/85-636

Pursuant to the Western Accord, the Petroleum Incentive Program terminated on March 31, 1986, with the exception of costs and expenses incurred upon Canada Lands in the case of grandfathered wells. Grandfathered wells on Canada Lands are generally those wells which were committed to on or before March 28, 1985 under either an exploration agreement or a written farmout agreement. These wells will continue to be eligible for incentive payments from April 1, 1986 to December 31, 1987, at which time all costs and expenses shall cease to be eligible. The Petroleum Incentive Program Act, S.C. 1980-81-82-83, c. 107 and the regulations SOR/82-666 have been amended to reflect the phase-out of this program.

\section{Canada Petroleum Resources Act, Bill C-92}

As this Supplement contains a separate paper on the Canada Petroleum Resources Act, Bill C-92, only the highlights of the Act will be discussed in this paper. The Act repeals and replaces the Canada Oil and Gas Act, S.C. 1980-81-82-83, c. 81. It applies to frontier lands which are essentially the Main Land Territories, Arctic Islands, Beaufort Sea, Hudson Bay, offshore east coast and offshore west coast. The Act provides that exploration rights are to be issued on a competitive basis using a bidding system. The $25 \%$ back-in of the Crown is abolished. The $50 \%$ Canadian ownership requirement is retained for discoveries after March 1982; however, the confiscatory provisions are repealed. This requirement will be enforced through a cooperative divestiture plan and an auction system. 
The royalty system is replaced with a sliding royalty increasing after payout, which is designed to limit the financial burden in the early years of production. The discretionary powers of the Minister with respect to drilling and production orders have been reduced and Petro-Canada will lose its preferred status.

\section{Canada Newfoundland Atlantic Accord Implementation Act, Bill C-94}

This Act implements the Atlantic Accord which was discussed in the version of this paper delivered last year, and only the highlights will be discussed here. The Act provides for the establishment of the CanadaNewfoundland Offshore Petroleum Board (the "Board") and the joint management by the Board of the petroleum resource activities in the prescribed offshore area. The provincial Government is authorized by the Act to establish and collect royalties and other provincial-type natural resource revenues and taxes. The Act provides for a joint offshore development fund of $\$ 300$ million to be financed $75 \%$ by the federal Government and $25 \%$ by the provincial Government, which is to be used to help meet the demands of oil and gas development in Newfoundland. An equalization offset payment formula is contained in the Act to ensure the province does not lose equalization payments. The Act also establishes an oil pollution and fisheries compensation regime and a public review process for oil and gas development.

\section{Canadian Laws Offshore Application Act, Bill C-104}

This Bill applies federal and provincial laws to the offshore areas. It declares that, for greater certainty, the seabed and subsoil below the internal waters and the territorial sea and any rights of Canada beyond the territorial sea with respect to the seabed, subsoil and their resources are vested in the Crown in the right of Canada, unless such areas of the sea are within a province. Federal laws apply to marine installations and artificial islands on the continental shelf and to a surrounding safety zone. The Governor in Council is given regulatory powers to apply federal laws to the continental shelf, any exclusive economic zone Canada may create and beyond the continental shelf by international agreement. Provincial laws apply (to the extent that such laws are not inconsistent with Federal laws) to the offshore area adjacent to the province which comprises part of the internal waters or territorial sea and to marine installations, artificial islands and to a surrounding safety zone. In addition, provincial laws are not applied if they impose taxes or royalties or relate to natural resources. The Governor in Council is given regulatory powers to apply provincial laws to the offshore in other circumstances. The Bill extends the jurisdiction of the courts to the offshore area and the application of the Criminal Code, R.S.C. 1970, c. C-34. The Immigration Act, S.C. 1976-77, c. 52 is amended to provide for regulations allowing persons routinely engaged in work in the offshore areas to re-enter Canada without examination. The Northwest Territories Act, R.S.C. 1970, c. N-22 is amended to make it clear that the Arctic archipelago forms part of the Northwest Territories. 


\section{B. FEDERAL REGULATIONS}

1. National Energy Board Part VI Regulation Amendments

\section{(a) SOR/85-390}

These amendments implement the agreement in the Western Accord to remove volume and price restrictions on short-term crude oil exports and to authorize short-term export approval on an "after the fact" basis. Provision has been made to allow the NEB to authorize by order the export of heavy oil for a period of up to two years and the export of all other crude oil for a period up to one year. Exports of crude oil for longer periods still require the issuance of a licence by the NEB. The amendments exempt from export controls, exported oil which is subsequently delivered to other parts of Canada. The importation of heavy fuel oil is also exempted from control.

\section{(a) SOR/85-446}

This amendment authorizes the importation and exportation of ethylene without a licence."

\section{(c) SOR/85-1049}

This amendment was made in conjunction with the Natural Gas Agreement. The NEB may, by order, authorize short-term exports of natural gas for up to a period of twenty-four months with no volume restrictions. It may also authorize the export of up to 30,000 cubic meters per day of natural gas for periods from two to twenty years. The regulations also adopt the adjacent border pricing test as the floor price for the natural gas authorized for export by such orders. The amendments allow the NEB to authorize by order the importation of up to 60 million cubic meters of natural gas for up to one year and 30,000 cubic meters per day of natural gas for one to twenty years.

\section{(d) SOR/86-33}

These amendments provide that a person must obtain special authorization from the NEB to export by marine vessel from the west coast of Canada certain high sulphur crude oils, and impose conditions in respect of these exports.

2. Pipelines Companies Records Preservation Regulations, Amendment SOR/85-897

This amendment establishes a fixed period of six years for the retention of certain records, and replaces the former requirement to retain records until the expiration of one year after leave to abandon the operation of the pipeline had been granted by the Board. 
3. Petroleum and Gas Revenue Tax Regulations, Amendment SOR/86-158

These amendments eliminate the ability to waive entitlement to a Petroleum Incentive Program payment for the purposes of a deduction of PGRT. The amendments apply to expenses incurred after 1985.

4. Nova Scotia Share Of Offshore Sales Tax Payment Regulation, SOR/85-912

These regulations prescribe the time, manner and calculation of the offshore sales tax payable pursuant to the Canada-Nova Scotia Oil and Gas Agreement Act, S.C. 1984, c. 29.

5. Canadian Ownership and Control Determination Regulations, 1984 Amendment SOR/85-847

These amendments simplify the method of calculating Canadian Ownership Rates, remove some substantive procedural requirements and clarify specific provisions relating to classes of forward equity and trusts.

6. Canadian Ownership and Control Determination Forms Order, 1985 SOR/85-846

This order prescribes the forms and manner for certificate applications filed on or after August 27, 1985.

7. Energy Monitoring Regulations, Amendment SOR/85-328

This amendment revises the information that is required to be filed. 